\title{
Does on-the-job informal learning in OECD countries differ by contract duration?
}

Citation for published version (APA):

Ferreira Sequeda, M. T., de Grip, A., \& van der Velden, R. K. W. (2015). Does on-the-job informal learning in OECD countries differ by contract duration? ROA. ROA Research Memoranda No. 008 https://doi.org/10.26481/umaror.2015008

Document status and date:

Published: 01/01/2015

DOI:

10.26481/umaror.2015008

Document Version:

Publisher's PDF, also known as Version of record

\section{Please check the document version of this publication:}

- A submitted manuscript is the version of the article upon submission and before peer-review. There can be important differences between the submitted version and the official published version of record.

People interested in the research are advised to contact the author for the final version of the publication, or visit the DOI to the publisher's website.

- The final author version and the galley proof are versions of the publication after peer review.

- The final published version features the final layout of the paper including the volume, issue and page numbers.

Link to publication

\footnotetext{
General rights rights.

- You may freely distribute the URL identifying the publication in the public portal. please follow below link for the End User Agreement:

www.umlib.nl/taverne-license

Take down policy

If you believe that this document breaches copyright please contact us at:

repository@maastrichtuniversity.nl

providing details and we will investigate your claim.
}

Copyright and moral rights for the publications made accessible in the public portal are retained by the authors and/or other copyright owners and it is a condition of accessing publications that users recognise and abide by the legal requirements associated with these

- Users may download and print one copy of any publication from the public portal for the purpose of private study or research.

- You may not further distribute the material or use it for any profit-making activity or commercial gain

If the publication is distributed under the terms of Article $25 \mathrm{fa}$ of the Dutch Copyright Act, indicated by the "Taverne" license above, 


\section{Does on-the-job informal learning in OECD countries differ by contract duration?}

Maria Ferreira Sequeda

Andries de Grip

Rolf van der Velden

\section{ROA Research Memorandum}

ROA-RM-2015/8

Researchcentrum voor Onderwijs en Arbeidsmarkt | ROA Research Centre for Education and the Labour Market | ROA 


\title{
Does on-the-job informal learning in OECD countries differ by contract duration?
}

\author{
Maria Ferreira Sequeda \\ Andries de Grip \\ Rolf van der Velden
}

ROA-RM-2015/8*

June 2015

Research Centre for Education and the Labour Market

Maastricht University

P.O. Box 616, 6200 MD Maastricht, The Netherlands

$\mathrm{T}+31433883647 \mathrm{~F}+31433884914$

secretary-roa-sbe@maastrichtuniversity.nl

www.roa.nl

\footnotetext{
* The ROA Research Memorandum Series was created in order to make research results available for discussion, before those results are submitted for publication in journals.
} 


\title{
Abstract \\ Does on-the-job informal learning in OECD countries differ by contract duration?**
}

Several studies have shown that employees with temporary contracts have a lower training participation than those who have a contract of indefinite duration. There is however no empirical literature on the difference in informal learning on-the-job between permanent and temporary workers. In this paper, we analyse this difference across twenty OECD countries using unique data from the recent PIAAC survey. Using an instrumented control function model with endogenous switching, we find that workers in temporary jobs engage in informal learning more intensively than their counterparts in permanent employment, although the former are, indeed, less likely to participate in formal training activities. In addition, we find evidence for complementarity between training and informal learning for both temporary and permanent employees. Our findings then suggest that temporary employment need not be dead-end jobs. Instead, temporary jobs with high learning content could be a stepping stone towards permanent employment. However, our results also suggest that labour market segmentation in OECD countries actually occurs within temporary employment due to the distinction between jobs with low and high learning opportunities.

JEL classification: E24, J24, J41

Keywords: temporary contracts, informal learning, training, human capital investments

\author{
Maria Ferreira Sequeda \\ Andries de Grip \\ Maastricht University \\ ROA \\ Maastricht University \\ P.O. Box 616 \\ ROA \\ NL-6200 MD Maastricht \\ P.O. Box 616 \\ The Netherlands \\ m.ferreirasequeda@maastrichtuniversity.nl \\ NL-6200 MD Maastricht \\ The Netherlands \\ and Industrial University of Santander \\ (Colombia) \\ a.degrip@maastrichtuniversity.nl \\ and IZA, Bonn (Germany) \\ Rolf van der Velden \\ Maastricht University \\ ROA \\ P.O. Box 616 \\ NL-6200 MD Maastricht \\ The Netherlands \\ r.vandervelden@maastrichtuniversity.nl
}

\footnotetext{
** We thank Olivier Marie, Bart Golsteyn, Trudie Schils, Lex Borghans, Annemarie Künn-Nelen, Alexandra de Gendre, Jeffrey Wooldridge, Denis de Crombrugghe and participants of the LEER Workshop on Education Economics (2015) and DUHR seminar Maastricht (2015) for their useful comments.
} 


\section{INTRODUCTION}

The expansion of temporary work has raised concerns about undesirable labour market inequality in many OECD countries. Various studies have found significant differences in wages as well as in training participation between permanent and temporary employees (e.g. Comi and Grasseni, 2012; Cutulli and Guetto, 2013; O’Connell and Byrne, 2010; OECD, 2014; Pfeifer, 2014; Steijn et al., 2006). However, other studies show that temporary jobs might increase transition probabilities into permanent employment, and could reduce unemployment rates (Booth et al., 2002; Cockx and Picchio, 2012; De Graaf-Zijl et al., 2011; Faccini, 2014; Gagliarducci, 2005; Jahn and Pozzoli, 2013).

Triggered by this trade-off, policy makers have stressed the importance of finding 'an appropriate balance between flexibility and security’ (European Commission, 2003) in order to prevent a part of the labour force being trapped in 'dead-end' jobs. Access to opportunities to develop workers' human capital is considered a crucial issue for many governments to create such a balance. In spite of this, little is known about the difference between temporary and permanent workers with respect to the intensity of on-the-job human capital investments in terms of informal learning. In this paper, we analyse and estimate that difference across 20 OECD countries, taking into account the potential endogeneity of the temporary work status. We use the unemployment rate as a valid identifying exclusion restriction to provide more precise information about the importance of informal learning in the context of human capital accumulation and potential career development of temporary employees.

Ideally, temporary work should function as a stepping stone that helps entrants to integrate into the labour market and then make the transition towards better stable employment. More on-the-job investments in human capital are expected to increase temporary workers' chances of finding permanent employment (Autor, 2001; Booth et al., 2002; De Graaf-Zijl et al., 2011; Gagliarducci, 2005; Jahn and Pozzoli, 2013). In view of that, OECD countries have shown a close interest in the securing of skills development at work and recognising informal learning as a rich source for it (OECD, 2010). The European Commission (2013; 2007) has explicitly considered lifelong learning strategies in the context of its so called flexicurity agenda.

Due to a lack of appropriate data, in particular of international comparability, there is hardly any empirical evidence on the difference between temporary and permanent workers with respect to the intensity of human capital investments on-the-job. The literature on this has, therefore, focused on training participation, although various studies have argued that employees spend much more time on informal learning activities that also contribute to the accumulation of human capital as a by-product of work (Cedefop, 2011; Koopmans et.al, 2006; Mincer, 1994; Nelen and De Grip, 2009). At the workplace, new skills and competences are informally acquired by workers while performing a 
combination of tasks, interacting with others, sensing the organisational culture, facing new jobrelated challenges, doing trial-and-error experimentation, and observing, reading, or simply executing their job (Billet, 2001; 2008; Koopmans et al., 2006; Marsick, 2009; Marsick et al., 2009; Tannenbaum et al., 2010).

Since individuals continue learning during their working career, the workplace is fundamental for human capital accumulation. On-the-job learning has been considered an investment that contributes to skills acquisition and, consequently, to have some positive effect on workers' productivity and wage gains (Blundell et al., 1999; Heckman, 1976; Killingsworth, 1982; Mincer 1968). However, in previous literature a concern has been raised about the quality of jobs and the opportunities for career development associated with temporary work (Arulampalam and Booth, 1998; Booth et al., 2002).

In this paper, we analyse to what extent the intensity of informal learning on-the-job differs between temporary and permanent employees. We thereby contribute to the literature in three ways. First, we assess the influence of temporary contracts on the on-the-job individual informal learning intensity across twenty OECD countries. Second, we raise the issue of endogeneity of temporary contracts due to possible selection into this kind of jobs, and account for the binary nature of the endogenous regressor. We estimate average treatment effects using an instrumented control function model with endogenous switching, using unemployment rates as selection instrument. Third, we explore the relation of substitution or complementarity between training and informal learning at the workplace for both temporary and permanent employees. For our empirical analyses we use the data from the OECD Programme for International Assessment of Adult Competences (PIAAC) study conducted in 2012. This survey contains very detailed information on workplace learning undertaken by workers.

Our results show that workers in temporary jobs engage more intensively in informal learning than their counterparts in permanent contracts, although the former, indeed, are less likely to participate in in formal training activities. In addition, we find evidence for a relation of complementarity between training and informal learning for both temporary and regular employees. Assuming that workers strongly prefer permanent contracts, we argue that temporary employees engage more intensively in informal workplace learning in order to increase their chances of upward mobility in the labour market.

The remainder of the paper is organised as follows. Section 2 discusses the literature related to our research question. Section 3 describes our empirical strategy and discusses the plausibility of the identifying assumptions. Section 4 presents the dataset, variables and summary statistics. Section 5 presents the main results and robustness checks. Section 6 assesses the question of complementarity between training and informal learning. Section 7 discusses the main findings and concludes. 


\section{RELATED LITERATURE}

In most OECD countries, laying-off workers with permanent contracts is costly and time consuming. However, the opportunity to employ some workers using temporary contracts gives firms the option to adjust the size of their labour force more easily. In this situation, employers have fewer incentives to invest in the human capital and long-term retention of those employees. The pursuit of flexible production by firms then has the potential to impose a negative externality on the welfare and skills development of the flex workforce (Arulampalam and Booth, 1998).

According to human capital theory, firms are less inclined to invest in training temporary workers, since the expected period in which they could benefit from these investments is relatively short. Several studies have provided empirical evidence of a negative relation between temporary contracts and training participation in different labour markets (e.g. Aruramplalan et al., 2011; Atkinson, 1998; Booth and Bryan, 2004; Cutulli and Guetto, 2013; Steijn et al., 2006; O’Connell and Byrne, 2010). A significant distinction of this negative relationship has been introduced by means of the matching approach. As firms and workers have imperfect information about the quality of the match and firms may use temporary contracts as a mechanism for screening workers, the negative effect of having a temporary contract on training may decrease with the quality of the job match (Akgündüz and Van Huizen, 2013; Jackson, 2012). Similarly, Acemoglu and Pischke (1999) show that employers will be encouraged to invest in general training of temporary employees due to the existence of labour market imperfections and the often compressed structure of wages in these non-competitive labour markets. Building on this, Autor (2001) tested a model in which firms offer training to induce self-selection and perform screening of high ability workers, prior to offering a permanent contract. He shows that firms providing training attract higher ability workers yet pay them lower wages after training. The key distinction is that in the human capital model, workers pay ex ante for general training, whereas in Autor's framework training costs and returns are shared ex post by trained workers and training firms. However, if training is transferable between employers with market power in setting wages, Stevens (1994) argues that other firms are very likely to benefit if they can poach the trained employees.

In addition to their participation in formal training activities, workers' human capital development is also affected by informal learning at the workplace. However, because of a lack of adequate data, there are hardly any empirical studies that focus on the relation between informal learning investments and temporary contracts. In human capital literature, informal learning has mainly been seen as learning-by-doing. Arrow (1962) was one of the first authors who emphasised the importance of learning-by-doing, as an automatic by-product of the regular production process. Mincer (1974) claimed that informal learning may constitute the essential part and the major investments on human capital provided by firms. Following Mincer's analysis, many studies have considered years of work experience as a proxy for these unobservable investments in non-formal learning. Killingsworth 
(1982), for instance, developed a model in which human capital accumulation occurs via both training and learning-by-doing. In this model, accumulation of training reduces workers' current earnings, while accumulation of experience does not. By devoting more time to learning-by-doing, workers can raise both current earnings and future productivity.

However, simply accumulating years of experience does not mean that a person will learn from it (Quinones et al., 1995; Tesluk and Jacobs, 1998), and not everyone is inherently good at learning from experiences (Maurer and Weiss, 2010). Moreover, jobs widely differ in their learning content potential and opportunities (Rosen, 1972). The quality of learning experiences at work depends on the degree to which the kind of job and the workplace offer people opportunities for undertaking challenging tasks, interacting with others, and organising their work (Billet, 2008; Cedefop, 2011). ${ }^{1}$

A more recent framework by Destré et al., (2008) states that workers can learn both by themselves and from others. This model provides a closed-form solution that revised Mincer and Jovanovic's (1981) treatment of tenure in the human capital earnings function by relating earnings to the individual's jobspecific learning potential. In such a setting, a worker's human capital increases with both training and tenure, and it converges towards the firm's job-specific knowledge, which is no longer fixed since workers are continuously learning by themselves and from each other. Some of the most emphasised implications of this study are that the supply of informal learning may be interpreted as tied into the workers' contract and that both direct and indirect costs of investments in formal training are expected to be higher than investments in informal learning. Therefore, workers might invest more time on the latter than on formal training activities, even though formal and informal human capital investments are likely to be complementary (De Grip and Smits, 2012; Nelen and De Grip, 2009).

Research on the 'stepping stone' effects of temporary employment has particularly argued that on-thejob skills development is probably the main mechanism through which temporary contracts offer a path into permanent jobs. ${ }^{2}$ These studies argue that transition odds likely increase with the improvement of human capital, work experience and general labour skills while being on assignment (Abraham, 1990; Autor, 2001; Booth et al., 2002; Cockx \& Picchio, 2012; De Graaf-Zijl et al., 2011; Dekker, 2007; Gagliarducci, 2005; Jahn and Rosholm, 2014; Jahn and Pozzoli, 2013). It is often claimed that temporary work may provide opportunities to gain experience and acquire human capital, to deepen the attachment to the labour market and to search more effectively for permanent jobs.

1. Informal workplace learning has mostly been studied in fields such as human resource development, management and organisation studies. This literature has primarily focused on the nature of individual and collective learning through everyday activity at the workplace, what organisational factors influence particular learning styles at work and selfdirected learning capability; and how to support and reward learning within firms (Billet, 2001; 2008; Cedefop, 2011; Keogh, 2009; Marsick et al., 2009; Svensson et al., 2004; Straka, 2000).

2. Besides, flex employees may increase learning investments for signalling reasons, due to the fact that employers can use temporary contracts to investigate the match and for screening of workers ability. 
Thus, from the perspective of the worker, taking up a temporary job with a high-learning potential instead of staying unemployed can be a good strategy to maximise lifetime income (Sicherman and Galor, 1990). Booth et al. (2002) and Berton et al. (2011), for instance, found that having a temporary contract at the beginning of the working career does not have a negative effect on workers' wage profiles. Those who start in flex jobs and move to permanent employment fully catch up to those who start in permanent jobs. Nonetheless, if temporary jobs are recurrent, the stepping stone effect decreases, training participation is lower and age-earnings profiles are flatter. In that case, temporary positions could be seen as dead-end jobs. ${ }^{3}$ All this suggests that temporary contracts are more effective in paving the way to stable employment if combined with human capital development (Dekker, 2007).

\section{EMPIRICAL STRATEGY}

Our primary regression equation of interest is

$$
\mathrm{IL}_{i}=\mathbf{x}_{i} \boldsymbol{\beta}+\delta \mathrm{T}_{i}+\mu_{i}
$$

where IL is a continuous variable, the on-the-job informal learning intensity for worker $i, \mathrm{X}$ is a vector of covariates composed by worker's and firm's characteristics along with a set of country dummies, and $\mathrm{T}$ is a binary indicator for the type of contract $(\mathrm{T}=1$ for employees on temporary contracts, $\mathrm{T}=0$ for employees on permanent contracts). All variables are described in the next section. For this model, the impact of temporary contracts on individual's informal learning intensity is measured by the estimate of $\delta$.

However, the binary indicator $T_{i}$ cannot be treated as exogenous since it is potentially based on individual self-selection or selection by employers. Unobservable characteristics of workers such as ability and motivation (Autor, 2001; Booth et al., 2002; Givord and Wilner, 2014; Loh, 1994; Mincer, 1994), but also time preferences and risk aversion (Belzil and Leonardi, 2007; Berton and Garibaldi, 2012; Mincer, 1994; Weiss, 1986) may affect both the temporary job and investment in informal learning decisions, resulting in biased estimates when using least squares. For instance, if the typical individual who is selected into temporary contracts would have relatively lower ability or lower motivation, then the OLS estimate of $\delta$ will actually underestimate the treatment effect. We might expect the bias to also be negative if most temporary employees would be workers who tend to have stronger time preferences for the present (or higher discount rate), or use to be below average riskaversion persons. If we feel these hypotheses are correct, then we would argue that $\delta$ underestimates the influence of temporary contracts on on-the-job informal learning intensity.

3. Usually workers with a less favoured labour position (youth, women and low educated) fall into this segment of temporary dead-end jobs. 
We account for the endogeneity of the temporary job selection by estimating an endogenous switching regression model of informal learning intensity where workers face two regimes, temporary and permanent employment (with only one regime observed). Following Heckman (1978), Heckman and Vytlacil (1999) and Heckman et al. (2001), the more general model is the following. The potential informal learning outcomes $\left(\mathrm{IL}_{0}, \mathrm{IL}_{1}\right)$ of the treatment $\mathrm{T}=(0,1)$ is assumed to depend linearly upon observable variables $\mathrm{X}$ and unobservables $\mu_{i}$ as in equation (1). The decision process for the temporary contract indicator is posed as a nonlinear function of observables $z$ and unobservables $v$, and linked to the observed outcome $\mathrm{IL}_{i}$ through the latent variable $\mathrm{T}^{*}$, as follows.

$$
\begin{gathered}
\mathrm{T}_{i}^{*}=\mathbf{z}_{i} \gamma-\mathrm{v}_{i} \quad(2) \\
\mathrm{T}_{i}= \begin{cases}1, & \text { if } \mathrm{T}_{\mathrm{i}}^{*}>0 \\
0, & \text { if } \mathrm{T}_{\mathrm{i}}^{*} \leq 0\end{cases} \\
\operatorname{Prob}\left(T_{i}=1 \mid \mathbf{z}_{i}\right)=\Phi\left(\mathbf{z}_{i} \boldsymbol{\gamma}\right) \\
\operatorname{Prob}\left(T_{i}=0 \mid \mathbf{z}_{i}\right)=1-\Phi\left(\mathbf{z}_{i} \boldsymbol{\gamma}\right)
\end{gathered}
$$

Consistent with our previous conjecture, the conditional independence assumption does not hold in these kinds of models. Instead, $\mu_{i}$ and $v_{i}$ are allowed to be correlated by a coefficient $\rho$, and assumed to be jointly normally distributed $\left(\mu_{i}, v_{i}\right) \sim N(0, \Sigma)$ (Greene, 2012; Maddala, 1983; Wooldridge, 2010). Under these assumptions, the bias caused by correlation of the regressor $\mathrm{T}$ with omitted variables is addressed by the non-zero expectation of the error term $\mu_{i}$ in equation (1), in the following manner.

$$
\begin{gathered}
\mathrm{E}\left(\mathrm{IL}_{i} \mid T_{i}=1, \mathbf{x}_{i}, \mathbf{z}_{i}\right)=\mathbf{x}_{i} \boldsymbol{\beta}+\delta+\rho \sigma_{\mu}\left[\frac{\phi\left(-\mathbf{z}_{i} \boldsymbol{\gamma}\right)}{\Phi\left(-\mathbf{z}_{i} \boldsymbol{\gamma}\right)}\right] \\
\mathrm{E}\left(\mathrm{IL}_{i} \mid T_{i}=0, \mathbf{x}_{i}, \mathbf{z}_{i}\right)=\mathbf{x}_{i} \boldsymbol{\beta}+\rho \sigma_{\mu}\left[\frac{-\phi\left(-\mathbf{z}_{i} \boldsymbol{\gamma}\right)}{1-\Phi\left(-\mathbf{z}_{i} \boldsymbol{\gamma}\right)}\right]
\end{gathered}
$$

Then, the expected difference in informal learning intensity between temporary and permanent employees is,

$$
\mathrm{E}\left(\mathrm{IL}_{i} \mid T_{i}=1, \mathbf{x}_{i}, \mathbf{z}_{i}\right)-\mathrm{E}\left(\mathrm{IL}_{i} \mid T_{i}=0, \mathbf{x}_{i}, \mathbf{z}_{i}\right)=\delta+\rho \sigma_{\mu}\left[\frac{\phi_{i}}{\Phi_{i}\left(1-\Phi_{i}\right)}\right]
$$

where $\phi$ and $\Phi$ are the standardised normal density and distribution functions respectively. The model is identified through exclusion restrictions. First, the nonlinearity of the selection equation, thus the correlation between $\mu_{i}$ and $v_{i}$, and second, by including variables in $\boldsymbol{z}$ that satisfy the following constraints: $\operatorname{Cov}\left(z, \mu_{i}\right)=0$, and $\gamma \neq 0$. In order to take account of selection into temporary employment based on observable and unobservable characteristics, we need a selection instrument that 
directly affects the incidence of temporary contracts but should not be related to potential confounders. For the model to be identified we use as instrument the unemployment rate of the year preceding the interview date by the corresponding country, gender and age group of the individual. We establish the admissibility of this instrument in Sections 4 and 5.

Control function (CF) estimators are the most used in the framework of endogenous switching regression models. Simple two-step procedures first estimate the model of endogenous regressors as a function of instruments, like the 'first stage' of 2SLS but through nonlinearities, and then use the generalised errors from this model as an additional regressor in the main model. Maximum likelihood methods simultaneously fit the continuous equation (1)-(3) and the binary equation (2) of the model in order to yield consistent and efficient estimates of the Average Treatment Effect (ATE) and consistent standard errors. Given the assumptions with respect to the distribution and correlation of the disturbance terms $\mu_{i}$ and $v_{i}$, the logarithmic likelihood function ${ }^{4}$ for the system of (1-2) is given in Maddala (1983):

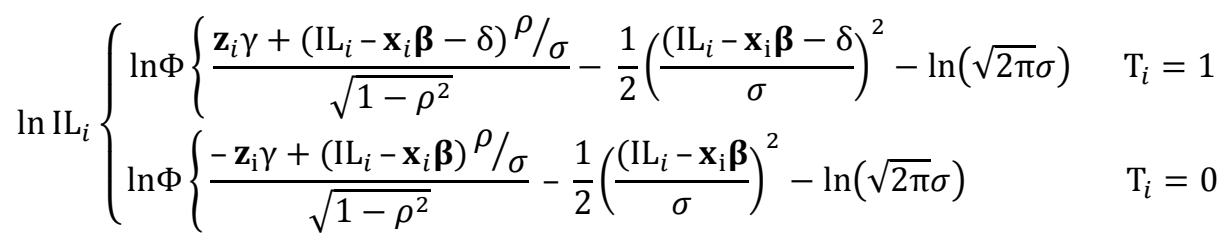

Furthermore, by also allowing that $\beta_{0} \neq \beta_{1}$ and $\sigma_{0}^{2} \neq \sigma_{1}^{2}$ where $\sigma^{2}$ represents the variance of $\mu_{i}$ in $\Sigma$, we obtain the full endogenous switching regression model in which the impact of the independent variables vary across regimes (Maddala, 1983; Wooldridge, 2010). Then the model (1) becomes,

$$
\mathrm{IL}_{i}=\mathbf{x}_{i} \boldsymbol{\beta}_{0}+\delta \mathrm{T}_{i}+\mathrm{T}_{i}\left(\mathbf{x}_{i}-\overline{\mathbf{x}}\right) \psi+\mu_{0}+\mathrm{T}_{i}\left(\mu_{1}-\mu_{0}\right)
$$

This model is very restrictive, because the treatment may create interaction effects with observed or unobserved personal characteristics (Maddala, 1983). This particular way of expressing the outcome model emphasises that we are primarily interested in $\delta$, although $\delta+\left(\mathbf{x}_{i}-\overline{\mathbf{x}}\right) \psi$ is of interest for studying how the ATE changes as a function of observables; that is to consistently estimate nonconstant treatment effects and average effects on the treated -ATT (Wooldridge, 2010). If $\left(\mu_{i}, v_{i}\right) \sim N(0, \Sigma)$, we obtain an identical representation to the endogenous switching regression model described before, also estimated by (4).

This control function approach derived in the context of endogenous switching regression models adds more structure to explicitly account for the binary nature of the endogenous regressor. If the nonlinear

4. It is fit by the Stata command etregress. Standard errors are approximated through the delta method. 
model gives better approximation to the conditional expected function of the treatment variable than the linear model, the resulting linear estimates will be more efficient than those using a linear first stage (Angriest \& Pischke, 2009; Newey, 1990; Wooldridge, 2010). This approach has some further advantages. It is appropriate for continuous selection instruments to be used for binary endogenous regressors (Imbens and Wooldridge, 2009). It distinguishes between excluded and included variables in outcome and treatment assignment equations and take advantage of exclusion restrictions to use the relevant information available to obtain identification (Heckman and Navarro-Lozano, 2004). Finally, it can be applied to estimate unconditional ATE and/or effects on the treated -ATT, thus allowing estimation of heterogeneous treatment effects (Angrist and Pischke, 2009; Wooldridge, 2010).

However, this approach, while likely more efficient than a direct IV approach, is less robust. Consistency of the control function estimator hinges on the bivariate normality assumption of $\mu_{i}$ and $v_{i}$; thus the probit equation be correctly specified in order to predict effectively which observations are selected into treatment. The better the prediction, the more precise estimates will be. Successful use of the control function method usually requires that at least one selection instrumental variable in $\boldsymbol{Z}$ not be included in $\mathbf{x}$ (Heckman, 1978; Heckman and Vytlacil, 2005; Wooldridge, 2010).

Since the benefit of increased precision of estimation might be at the cost of greater chance of misspecification error, we perform various robustness checks of our CF estimations. One important robustness check is based on the Wooldridge's (2003, 2010) robust approach. He demonstrates that, under weaker distributional and functional assumptions, an alternative instrumental variables estimator can be consistently applied to estimate homogeneous and heterogeneous effects of a discrete endogenous variable. The alternative is using the probit fitted values for each $\mathrm{T}_{i}$ as valid generated IVs in a simple 2SLS procedure. Then, the first-stage estimations are not needed to be correctly specified as it is required in the control function approach. This method is more efficient than direct 2SLS methods and fully robust to misspecification of the probit model, yet it is less efficient than the control function estimator if the additional assumptions needed for control function consistency hold (Wooldridge 2003, 2010).

\section{DATA AND DESCRIPTIVE STATISTICS}

\subsection{Data and sample}

We use data from the OECD Programme for the International Assessment of Adult Competencies (PIAAC) survey, conducted between 2011 and 2012 in 24 industrialised countries and based on a representative sample of the population of the OECD participant countries. ${ }^{5}$ This is a unique dataset that measures the incidence of training as well as the intensity of on-the-job informal learning. The

5. See OECD (2014b) for further details about validation of data. 
latter measure which is not available in any other large scale dataset is based on a conceptual framework that takes account of three pathways of learning, namely learning-by-doing, learning from others and learning from keeping up-to-date with new products or services.

We restricted the sample to include full-time ${ }^{6}$ employed males ${ }^{7}$, excluding self-employed and armed forces employees, aged 17 to 65 , not participating in any formal education programme, who have an employment contract different from an apprenticeship. The sample size is 25,366 observations balanced $^{8}$ in 20 OECD countries ${ }^{9}, 88.2$ percent permanent positions and 11.8 percent temporary contracts. The distribution of permanent and temporary contracts in the sample coincides with the population distribution, according to the OECD statistics published for 2012 (See Table 1).

[Insert Table 1 about here]

\subsection{Variables}

Dependent (outcome) variables

1. On-the-job informal learning intensity is a standardised index ${ }^{10}$ derived from the following questions; all three measured in a five-point Likert scale: ${ }^{11}$

a) How often do you learn new work-related things from co-workers or supervisors?

b) How often does your job involve learning-by-doing from the tasks you perform?

c) How often does your job involve keeping up to date with new products or services?

This variable takes the lowest value if all the three questions were answered 'never' and the highest if 'every day'. To facilitate the interpretation of results, the variable was standardised. In addition, a

6. We consider full-time employees those who reported a minimum of 35 working hours a week.

7. We focus on males due to the higher probability of working career interruptions among women. This makes temporary jobs to differ in significance between men and women since women may prefer career flexibility through a significant portion of their working lives (Booth et al., 2002).

8. In Canada the sample existed of some 5,044 cases, from which we took a random sample of 23.1 percent, resulting in 1,165 cases to reduce possible bias due to oversampling of Canadian respondents.

9. Four countries were excluded from our sample: Australia, Cyprus, Russian Federation and the United States. Australian data was not available due to data confidentiality reasons. OECD statistics for Cyprus are not available. Data from the Russian Federation was preliminary and considered by PIAAC not representative of the population since Moscow was excluded from the survey. Finally, the particular characteristics of the labour market of the United States lead to a loss of 58 percent of observations due to employees who stated not to have a contract at all. In that case, only 387 nonrandom observations would remain in our sample, from which 31.3 percent would presumably correspond to temporary jobs, a percentage very different from the OECD statistic that estimates only 4.2 percent temporary employment in the US. Therefore, our main variable of interest would capture something different in the US, not comparable to other countries. As shown by the ILO (2010) and the OECD (2006), due to very low employment protection legislation, the distinction between temporary and permanent employment is of much less significance in the United States.

10. This index was derived by PIAAC from the d_q13 set of questions using the generalised partial credit model (GPCM) and estimated by weighted likelihood estimation (WLE). Its validity was assessed based on cross-country comparability, scale reliability and scale correlations. For further details, see OECD (2014b). The index cannot be estimated for 554 respondents in our sample that reported 'never' in all three d_q13 questions; therefore, the lowest value of the index by country was imputed to those observations. The findings are robust to different constructions of the index, e.g. very similar results are obtained by using the standardised principal component factor of the three statements.

11. Item response rate to these questions was about 98 percent. Answer options: 1) never; 2) less than once a month; 3) less than once a week but at least once a month; 4) at least once a week but not every day; and 5) every day. 
dummy variable for on-the-job informal learning incidence was derived. It takes the value 0 when the previous questions are all answered 'never', 1 otherwise.

2. Training incidence is a dummy variable of participation in job-related training during the previous 12 months. It is based on the following questions: During the last 12 months, have you...

a) Participated in courses conducted through open or distance education?

b) Attended any organised sessions for on-the-job training or training by supervisors/co-workers?

c) Participated in seminars or workshops?

d) Participated in courses or private lessons, not already reported?

This variable takes the value 1 if the person participated in any of the mentioned training activities and the current/last training activity was reported to be mainly job-related. It takes the value 0 otherwise ${ }^{12}$.

\section{Explanatory variable}

Temporary contract ${ }^{13}$ : a dummy variable that takes the value 1 for temporary contracts and 0 for permanent contracts. Temporary contracts in our sample include fixed-term positions (90.5 percent) and agency work (9.5 percent). ${ }^{14}$

Control variables: The questionnaire contains detailed information about individual, current job and firm characteristics. As suggested by earlier research, we control for age, educational levels (highest level of education obtained imputed into years of education), educational mismatch (dummies for overeducation and undereducation) ${ }^{15}$, employer tenure, actual weekly working hours (top-coded at 60), elaborate learning ${ }^{16}$; and firm size (five categories), occupation (nine ISCO 1-digit categories), industry (ten ISIC 1-digit categories) and country dummies.

12. Item response rate to these questions was about 90 percent.

13. According to the OECD concepts, permanent workers are, in general, persons whose main job is of indefinite duration. A job may be regarded as temporary if it is understood by both the employer and the employee that the duration of the job is limited.

14. It is derived from the question: What kind of employment contract do you have? The answer options are: 1) an indefinite contract; 2) a fixed term contract; 3) a temporary employment agency contract; 4) an apprenticeship or other training scheme, 5) no contract.

15. These dummies are derived from the question: Thinking about whether this qualification is necessary for doing your job satisfactorily, which of the following statements would be most true? Answer options: 1) This level is necessary; 2) A lower level would be sufficient; and 3) A higher level would be needed.

16. According to OECD (2014b), this item aims to measure the extent of elaborate learning, based on the approach of Kirby et al. (2003). It is considered a stable personal characteristic, named by PIACC as readiness to learn. Elaborate learning is the metacognitive ability to integrate new information with previous knowledge, synthesise new material and make connections to form a wider perspective. It structures the learning process and affects the efficiency with which new information is being processed. Therefore, it also describes learners' interest in learning and informationprocessing strategies. In the context of PIAAC, elaborate learning aims to capture how people approach learning situations especially at the workplace. We use the standardised index of readiness to learn derived by PIAAC from the following questions, all measured in a five-point Likert scale: 1) When I hear or read about new ideas, I try to relate them to real life situations to which they might apply; 2) I like learning new things; 3) When I come across something new, I try to relate it to what I already know; 4) I like to get to the bottom of difficult things; 5) I like to figure out how different ideas fit together; and 6) If I don't understand something, I look for additional info to make it clearer. 


\section{Selection instrument variable}

We use the unemployment rate as the selection instrument in our estimations. We collected OECD data on annual male unemployment by country and five-year age groups for 2010 and 2011 . We matched this data to the individuals by corresponding country, age and year of the interview.

The unemployment rates likely represent a suitable instrument for the individual probability of having a temporary contract, which is uncorrelated with the error term $\mu_{i}$, due to the following two reasons. First, unemployment measures have been shown to be correlated to subsequent temporary employment incidence. The average likelihood that workers will be in temporary jobs rises primarily when the unemployment rate is relatively high (Jahn and Bentzen, 2012; Kahn, 2010). That is expected since temporary jobs have been promoted as a mechanism to improve the labour market integration of the unemployed (Gagliarducci, 2005; Gebel, 2013) and because a higher unemployment rate often means a risk for active working population and job seekers that reduces the chance of finding more stable employment (European Commission, 2010). When economic prospects are poor, workers anticipate that opportunities in the labour market will be scarce, and they will, thus, with higher probability accept temporary contracts (Abraham, 1990; Givord and Wilner, 2014). From a demand side point of view, employers add greater value to the use of temporary employment as a low cost short-run buffer when there is excess supply in the labour market or if the labour market is regulated by stringent permanent job security provisions (Gagliarducci, 2005; Kahn, 2010).

Second, there is no reason to expect that unemployment rates at the country level directly affect decisions on informal learning investments on-the-job, except through the kind of contract an employee has. Higher unemployment rates might raise tenure uncertainty at the firm and, therefore, incentivise greater investments in human capital on-the-job; however, uncertainty mainly depends on whether the contract is of indefinite or fixed duration.

The relationship between unemployment and the probability of having a temporary contract may, however, differ by country because of the strictness of employment protection legislation (EPL). Stricter rules applicable to permanent employment may tend to increase the incidence of temporary work and to limit the extent to which temporary contracts will be converted into permanent ones (Booth et al., 2002; Gagliarducci, 2005; Kahn, 2010; OECD, 2004; Sala et al., 2012). We therefore use version 3 of the EPL indicator for regular employment ${ }^{17}$ (standardised and categorised in 3 dummies) to interact with our selection instrument.

17. This indicator is the weighted sum of 13 data items concerning the regulations for individual dismissals and additional provisions for collective dismissals. It is measured on a scale from 0 (least restrictions/strictness) to 6 (most restrictions/strictness). A higher score means a higher level of employment protection. 


\subsection{Descriptive statistics}

Table 2 presents summary statistics for the permanent and the temporary workers, respectively. As expected, temporary employees in our sample are generally younger, and have fewer years of work experience and tenure than permanent workers. Moreover, among individuals in temporary positions there is a higher share of overeducated workers, and a lower proportion employed in skilled occupations, large firms and the tertiary sector of the economy. It is worth mentioning that there is no descriptive difference between permanent and temporary employees regarding years of education and elaborate learning.

Regarding our variables of interest, we first observe that practically every person learns something onthe-job (98 percent informal learning incidence), with no significant difference by type of contract. However, flex workers show a greater mean of informal learning intensity. This makes it more interesting to analyse the intensity of informal learning rather than the incidence. In contrast, we observe that permanent employees more often participate in job-related training. In our sample, 91.7 percent of training participation was totally or mostly financed by firms while 8.3 percent was financed by workers. Likewise, 83.3 percent of trained workers followed training only or mostly during working hours, while 16.7 percent did it mostly or entirely outside working hours. All this suggests that firms are the main initiators and funders of training, although there is also room for employee initiative.

Finally, data confirm that temporary workers faced on average 3 percentage points higher unemployment rates during the previous year than the rates corresponding to permanent employees. The simple Pearson's correlation confirmed that the unemployment rate is significantly correlated to the country incidence of temporary contracts by 0.50 and to the temporary contract dummy of our sample by 0.56 (See Figure A1 in the appendix). Similarly, we observe that the average level of EPL applicable to permanent employment is slightly higher for the group of temporary workers in our sample.

\section{[Insert Table 2 about here]}

\section{ON-THE-JOB INFORMAL LEARNING INTENSITY}

\subsection{Main findings}

The main results of the regressions for on-the-job informal learning intensity are presented in the upper panel of Table 3. To assess the results of taking selection into temporary jobs into account, Table 3 proceeds stepwise. The first specification gives the results of an ordinary OLS regression. Specifications (2) and (3) show the coefficients from standard 2SLS estimations that only take account 
of self-selection. The last specifications (4) and (5) provide the control function estimates derived in the context of the endogenous switching regression model as described in Section 3, which not only take the endogeneity of the type of contract into consideration but in addition explicitly account for the binary nature of the endogenous regressor. The latter coefficients were obtained by maximum likelihood. The second section of Table 3 shows the corresponding first stage/treatment estimates of the temporary contract equation. ${ }^{18}$

Overall, results in Table 3 provide remarkable evidence of a positive difference in on-the-job informal learning intensity between temporary and permanent employees, in favour of the former group. Compared with the standard OLS estimates, the other coefficients that account for the endogeneity of temporary contract selection are adjusted upwards, as we expected. We consider the estimates generated by the control function approach more precise and proceed with interpretation. Further arguments on the accuracy of these estimates will follow.

The results in columns (4) and (5) indicate, indeed, that the OLS coefficient of temporary contracts is biased downwards. Once the selection into the contract type is controlled for, the estimated ATE of interest increases from 0.095 to 0.17 of a standard deviation. This implies that workers in temporary jobs invest, on average, 0.17 of a standard deviation more in informal learning on-the-job than their counterparts in permanent employment. The estimated correlation between the temporary contract equation errors and the outcome errors $\rho$ is negative $(-0.075)$, indicating that unobservables that raise informal learning intensity tend to occur with unobservables that lower temporary contract selection. This is coherent with our hypothesis of unobservables mentioned in Section 3. For instance, people with greater ability or motivation and larger time preference for the future are less likely to be selected into temporary jobs at the same time that they are also more likely to engage more in job training and informal learning (Mincer, 1994).

In comparison with the OLS estimates, the CF coefficients and standard errors of the exogenous regressors change much less. Most of the control variables in our regressions affect the dependent variable in the expected direction by the human capital theory. We find that on-the-job informal learning intensity decreases with age as the lifecycle theory of human capital predicts. The squared term of age is positive and significant which denotes a turning up point of investments at the end of the working life. It might be seen as a rational action to counterbalance the depreciation of human capital at an older age, as suggested in the literature (e.g. Destré et al., 2008; Heckman, 1976; Killingsworth, 1982).

18. Tables A1 and A2 in the appendix show other more restricted specifications of the endogenous switching model to see how the main estimated coefficient of temporary contracts changes with the progressive introduction of control variables. 
Years of education correlate positively with intensity of learning at the workplace. On average, one additional year of schooling increases informal learning by 0.016 of a standard deviation. This complementarity may arise because of the self-productivity of human capital accumulated through formal schooling, which may increase ability to learn and be useful for informal learning on-the-job (Rosen 1972). Yet, educational mismatches seem to have an important impact on this relationship. With respect to the well matched, overeducated employees tend to invest, on average, 0.11 of a standard deviation less in informal learning while undereducated employees invest 0.15 of a standard deviation more. This is consistent with Jahn and Pozzoli (2013) who hypothesize that temporary workers employed below their skill level will be less likely to improve their human capital. ${ }^{19}$

There is also a positive relation of informal learning intensity with elaborate learning and actual working hours, and a negative relation with tenure. The latter is attributed to the larger learning exposure of workers when they are new to their jobs. We also find that informal learning intensity at the workplace tends to be significantly higher for individuals employed in high-skilled occupations and larger firms. There are also some significant differences across industries and countries.

\section{[Insert Table 3 about here]}

We favour the CF specifications for various reasons. First, we observe that they provide more accurate predicted probabilities in the temporary contract equation. Linear prediction from the 2SLS first stage runs from -0.20 to 0.76 , leaving 16 percent of the sample predicted probabilities below 0 . In contrast, probit predicted probabilities run from 0 to 0.92 , allowing better common support for the treatment parameters to be defined. Therefore, we presume the outcome equation estimates to be more efficient in the second case. Second, the size of the instruments coefficients significantly differ between 2SLS and CF specifications. In column (4), for instance, an increase of one standard deviation in the unemployment rate, on average, increases the probability of being in a temporary job by 1.6 percentage points. In column (2), the same effect predicted by the 2SLS first stage is approximately 4.7 percent, 3 times bigger. The size of the probit marginal effect is relatively closer to related research, for example, Kahn (2010).

Third, we are carefully selective in the inclusion of covariates in the temporary contract equation in columns (4) and (5), which is not allowed in the standard 2SLS framework. As suggested by related literature, we do not include tenure, working hours, and educational mismatches as determinants of temporary contract selection. Even so, we perform further robustness checks of this treatment equation

19. Our estimations control for the fact that workers have a job at the appropriate level. Nonetheless, estimations that do not control for educational mismatches give a very similar and significant coefficient for temporary contracts $(0.163$ and 0.165 of a standard deviation using one and three instruments, respectively. See specifications (5) in Tables A1 and A2). 
specification. Fourth, we observe some implausible estimates in the 2SLS outcome equations such as the positive non-significant coefficients of age and tenure. Fifth, the Wald tests for specifications (4) and (5) indicate at 95 percent confidence that we can reject the null hypothesis of no correlation between the errors of the temporary contract and the outcome equations, so that our instrumented endogenous switching regression models fit well overall. An important argument in favour of these models and our instrument is that the Wald test after the CF estimation that does not include any instrument, which means relying identification only upon nonlinearities, cannot reject the null. Additionally, concerning the admissibility of our instrument, it is worth mentioning that Wald and Ftests after nonlinear and linear first-stage estimations, respectively, show that our instrumental variable included in addition to the other covariates makes a significant contribution to the model of interest. Last but not least, in contrast to the CF approach, 2SLS does not provide average treatment effects but local average treatment effects; the former being more policy-relevant in the context of our research question.

We conclude that the ATE of temporary contracts on the intensity of informal learning on-the-job is positive and approximately 0.17 of a standard deviation in the OECD countries included in our sample. The size of this coefficient is substantial if we consider that it is almost the same as the impact of ten years of schooling. Assuming that full-time male workers have generally stronger preferences for permanent contracts (Booth et al., 2002; Jahn and Bentzen, 2012), we hypothesise that flex employees will rationally engage more on workplace informal learning increase their chances of transition to more stable jobs with current or potential future employers. Thus, it could be expected that those individuals with expectations of upward mobility in the labour market will be more likely to invest more in informal learning on-the-job. ${ }^{20}$

\subsection{Robustness of main results}

In this section we present various robustness checks of the previous results, mainly related to the sensitivity of our main estimation to alternative treatment specifications. All results in this section are shown in the Appendix.

The first concern we address is the robustness of our CF estimations with respect to different specifications of the probit model. We tested a range of models and present summary results in the appendix, Table A3.

20. This finding might be related to Engellandta and Riphahn (2005) study who found that temporary workers in Switzerland provide higher effort than permanent employees by using indicators for unpaid overtime work. They also suggest that implicit incentives of shifting to permanent employment might explain those results. 
Specifications (2) to (6) include variables that we do not consider as determinants of temporary contract selection in Table 3. We note that including these regressors does not substantially change the main estimates. Only when tenure is included as an explanatory variable for temporary contracts do we see that the estimated ATE of interest increases from 0.17 to 0.22 of a standard deviation, which indicates that our results are conservative. Moreover, the predicted values of $\rho$ remain negative and the Wald tests are significant in all these specifications, meaning that our main results hold.

The specifications (7) to (12) exclude variables we included as determinants of temporary contract selection in our main estimations. The results in Table A3 show that the ATE of temporary contracts on informal learning intensity is almost identical to that of Table 3. Only when country dummies are excluded from the probit model do we observe an increase in the estimated ATE of interest from 0.17 to 0.22 of a standard deviation. This suggests that country-fixed effects are important controls for unobserved heterogeneity between countries. Moreover, the predicted values of $\rho$ remain negative in these alternative models. The Wald tests are all significant at 95 percent confidence with the only exception of models excluding occupation dummies that are significant at 90 percent instead.

A second concern is a possible misspecification of the treatment equation due to relevant covariates we do not observe. When we assess the accuracy of our main results in contrast to those provided by the Wooldridge's robust estimator described in Section 3, we find that the coefficients of the temporary contract indicator remain highly significant and positive (See Table A4). These estimators are downwards adjusted in comparison with the standard 2SLS results of Table 3; however, they are approximately seven and four times larger than the corresponding OLS and CF estimators, respectively. This shows that although Wooldridge's approach is more efficient that the direct 2SLS procedure and fully robust to misspecification of the probit model, it is less efficient than the control function method in this particular case.

\subsection{Heterogeneous effects}

\section{Heterogeneous workers}

Although temporary workers are on average more intensively engaged in informal learning, this might differ among temporary workers with different characteristics. Temporary employees could for instance have different expectations on their career prospects. If that is the case, we might expect distinct levels of informal learning intensity of temporary workers depending on their age and tenure: particularly younger workers and those with lower tenure might have stronger incentives to engage in learning when they are employed in a temporary job as this might help them to acquire a permanent contract. We might expect that these investments in informal learning are more beneficial for temporary workers earlier in their career when they have better expectations of transferring to a permanent position. 
To investigate the possible heterogeneity of informal learning intensity, we estimate full endogenous switching regression models to allow all coefficients of covariates to vary over the treatment level, as has been explained in Section 3. The results shown in Table 4 indicate that after allowing for heterogeneous response to treatment, our main conclusion still holds. Both the ATE and ATT remain significant and positive; the latter being of similar size to the ATE estimated in Table 3. We find that workers with temporary contracts invest, on average, 0.13 of a standard deviation ${ }^{21}$ more in workplace learning than workers with permanent contracts. The ATT shows that temporary employees actually invest 0.18 of a standard deviation more in informal learning than if they had contracts of indefinite duration.

These models allowing for heterogeneity show that coefficients on age, age squared, tenure and working hours significantly differ by type of contract while years of education, overeducation, undereducation, and elaborate learning do not. The coefficients confirm our expectations that the rate at which informal learning intensity decreases with age and tenure is larger when someone has a temporary contract. This suggests that the mean estimate of temporary contracts in our informal learning model is mainly driven by the temporary employees who are younger and have had tenure for fewer years.

\section{[Insert Table 4 about here]}

More precisely, the significant difference in the coefficient of age between temporary and permanent employees suggests that being a year older decreases the intensity of informal learning on average by 0.0218 of a standard deviation in the case of employees with permanent contracts, and by 0.0265 in the case of temporary contract workers. As mentioned previously, larger investments in informal learning of temporary workers are expected to be more beneficial earlier in the job career when workers have better prospects on gaining a permanent position. This suggests that at some point in the life course the difference in informal learning between permanent and temporary employees will vanish, nevertheless not just a young early career effect. According to the estimations (1) and (2) in Table 4, the positive marginal effect of temporary contracts on informal learning intensity becomes insignificant (at the 95 percent confidence level) after the age of 47 (See Figure 1). The table also shows that the coefficient of age squared is only significantly different from zero for permanent employees. This suggests that the turning up point of informal learning investments at the end of the working life particularly holds for workers with a permanent contract.

\section{[Insert Figure 1 about here]}

21. The correspondent ATE estimated by running two separate OLS regressions is 0.075 , significant at 99 percent confidence. 
Similarly, the results in Table 4 show that the negative coefficient of tenure is significantly larger for employees with temporary contracts. For permanent employees, one additional year of tenure reduces the informal learning intensity by 0.0024 of a standard deviation, compared with 0.0082 for temporary workers. This suggests that the higher intensity of informal learning for temporary workers particularly holds for employees with fewer years of tenure. This again indicates that this effect ends gradually. We find at 95 percent of confidence that the positive marginal effect of temporary contracts on informal learning intensity disappears after approximately 7 years of tenure (See Figure 2). This may be due to temporary workers adjusting their expectations of labour mobility when they feel to be trapped in a temporary job. As mentioned previously, this suggests that workers who remain employed in a temporary job for a long time are actually employed in dead-end jobs without any career prospects.

\section{[Insert Figure 2 about here]}

\section{Heterogeneous job tasks}

It might be the case that our estimates are driven by different correlated job tasks. For instance, it could be that employees in high skilled jobs or in jobs that offer more task complexity, task discretion, and flexibility are more often engaged in informal learning at work. To test this expectation, we construct dummy variables for different job content characteristics and calculate heterogeneous effects on informal learning via interaction terms between these dummies and temporary contracts, as explained in Section 3. The corresponding results are presented in Table 5.

\section{[Insert Table 5 about here]}

The estimation results show that all employees, regardless of the kind of contract they have, tend to engage more intensively in informal learning when they are employed in high skilled jobs ${ }^{22}$ or have a job in which they have higher levels of task discretion ${ }^{23}$, are more often confronted with simple ${ }^{24}$ and complex ${ }^{25}$ problems, are more often involved in team work ${ }^{26}$, more often use ICT at work ${ }^{27}$, and more

22. This dummy takes the value 1 for employees in ISCO occupation categories 1 to 3 . It takes the value 0 for employees in ISCO occupation categories 4 to 9 .

23. This dummy takes the value 1 for the highest two quantiles of an index derived from the following questions, all measured in a five-point Likert scale. To what extent can you choose or change: a) the sequence of your tasks?, b) how you do your work?, c) the speed or rate at which you work?; and d) your working hours? It takes the value 0 otherwise.

24. This dummy takes the value 1 if the person answered one of the two highest frequency values to the question: how often are you usually faced by relatively simple problems that take no more than 5 minutes to think about a good solution? It takes the value 0 otherwise.

25. This dummy takes the value 1 if the employee answered one of the two highest frequency values to the question: how often are you usually confronted with more complex problems that take at least 30 minutes to think about a good solution? It takes the value 0 otherwise. 
often perform planning ${ }^{28}$ tasks. However, this does not differ between those with temporary or permanent contracts. These results suggest that our main conclusion holds, even after controlling for observable job content characteristics. In all cases, the ATE remains highly significant and very close to that of Table 3; again supporting the idea that differences in career prospects due to the type of contract is the driver of our findings.

\section{INFORMAL LEARNING AND TRAINING: SUBSTITUTION OR COMPLEMENTARITY?}

\subsection{Training incidence}

To assess the substitutability or complementarity between informal learning and training, we first perform estimations to validate in our sample the negative association of temporary contracts to training participation found in other studies. For this analysis, the sample size is reduced to 22,447 observations of employees who reported valid information on the job-related training variable, excluding those who were unemployed when followed the training. ${ }^{29}$ Table 6 provides the results and proceeds stepwise.

\section{[Insert Table 6 about here]}

The temporary contract indicator yields the expected negative coefficient in all estimations. The coefficient given by the standard probit (2) is just slightly higher compared with the OLS specification (1). The results in columns (3) and (4) indicate that the OLS and probit estimations can be considered biased downwards to some extent. Once the selection into the contract type is controlled for, the estimated temporary contract penalty to participate in training increases from 6.5 to 7.6 percentage points. This implies that workers in temporary jobs are, on average, 7.6 percent less likely to take part in job-related training activities than individuals in permanent employment.

The negative value of $\rho$ suggests that unobservables that decrease temporary contract selection probably occur with unobservables that increase training participation chances. This is again in line

26. This dummy takes the value 1 if the employee answered one of the two highest proportion values to the question: In your job what proportion of your time do you usually spend collaborating with co-workers? It takes the value 0 otherwise.

27. This dummy takes the value 1 for the highest two quantiles of an index derived from the following questions, all measured in a five-point Likert scale. In your job, how often do you usually: a) use email?; b) use the internet in order to better understand issues related to your work?; c) conduct transactions on the internet?; d) use spreadsheet software?; e) use a word processor?; and f) participate in real-time discussions on the internet? It takes the value 0 otherwise.

28. This dummy takes the value 1 for the highest two quantiles of an index derived from the following questions, all measured in a five-point Likert scale. How often does your usually involve: a) planning your own activities?; b) planning the activities of others?; and c) organising your own time? It takes the value 0 otherwise.

29. Due to this reason, we excluded 364 observations from the estimations. 
with our hypothesis of unobservables mentioned in Section 3. However, in the $\mathrm{CF}^{30}$ specifications (3) and (4), the Wald tests indicate that we cannot reject the null hypothesis of $\rho=0$ at 95 percent confidence, but at 90 percent. This means that at 95 percent of confidence, temporary contract selection could still be considered exogenous to the model of training participation; therefore, probit estimation (2) would be reliable. In any case, the probit and CF estimates are of comparable size and significance.

The results in Table 6 confirm the disadvantage of temporary workers accessing job-related training as it has been widely evidenced in the literature (e.g. Albert et al., 2010; Arulampalam et al., 2004; Booth and Bryan, 2004; Cutulli and Guetto, 2013; Steijn et al., 2006; O’Connell and Byrne, 2010). In addition, we find that the effect of age on training probability is positive early in the working career, but rapidly turns into a negative as the significant coefficient of age squared indicates. It is shown in specifications (3) and (4) that the probability of participation in training is positive until workers reach nearly age 35 and subsequently it starts decreasing. This is consistent with the lifecycle model of human capital accumulation (Ben Porath, 1967) and empirical studies' findings (e.g. Grund and Martin, 2012; O’Connell and Byrne, 2010).

The probability of training also rises with years of education. On average, every additional year of schooling increases the chances of participating in job-related training by 1.7 percentage points. Educational mismatches also have an important impact on training as they have on informal learning. With respect to the well matched, overeducated employees are 1.8 percent less likely to take part in training activities while undereducated are 2.8 percent more likely. There is also a positive relation between training probability and elaborate learning, actual working hours, and tenure. ${ }^{31}$ The latter because it may be optimal to delay training if there is belated information about well matches and employees' future mobility (Loewenstein and Spletze, 1997).

\subsection{Complementarity}

We have found that although workers on temporary contracts are less likely to participate in training, they engage more intensively in informal learning. This raises the question of whether or not for temporary workers informal workplace learning is a substitute of training.

To answer this question it would be possible to first observe whether there is a difference in the informal learning intensity of employees who undertook any training and those who did not. Figures 3

30. Since maximum likelihood estimation of endogenous switching models for binary outcome variables follows a different structure and notation, the Stata command etregress is not appropriate. We then used the wrapper program ssm to obtain the do-file to fit the correspondent models (4) and (5) with the gllamm command. For a detail description, see Miranda and Rabe-Hesketh (2006) and Rabe-Hesketh et al. (2005).

31. After controlling for age squared, the squared term of tenure was not significant in any of the equations. Therefore we kept the former and did not include the latter. 
and 4 graphically present this difference among temporary and permanent workers, respectively. Both figures suggest a positive relation between job-related training and informal learning since the intensity of investments in the latter is shown to be consistently greater when the incidence of training is positive. Figure 3 indicates that workers on temporary contracts do not seem to substitute for the lack of formal training with informal learning: when they have the opportunity to participate in training, they engage more in informal learning.

\section{[Insert Figure 3 and Figure 4 about here]}

To test whether or not there is, indeed, complementarity between training and informal learning, we include training participation and its interaction with the type of contract in our main equation of informal learning. Table 7 shows that the positive relation between informal learning and job-related training holds after controlling for various individual and employer characteristics. Moreover, the magnitude of this complementarity does not differ by type of contract as the interaction term of training and temporary contract is not statistically significant in all three estimations, which means that the direction and size of the regarded complementarity for temporary workers runs equally to the complementarity estimated for permanent employees. On average, taking part in job-related training increases informal learning by 0.19 of a standard deviation. Moreover, the estimated results show that flex workforce engage more intensively in informal learning even after controlling for job-related training participation.

[Insert Table 7 about here]

\section{CONCLUSIONS AND DISCUSSION}

In this paper, we have analysed the difference in informal workplace learning intensity between permanent and temporary male employees across twenty OECD countries. Human capital theory would predict both firms and employees to be less willing to invest in skills if workers are hired under temporary contracts. Remarkably, we found significant evidence that workers in temporary jobs engage more intensively in informal learning on-the-job than their counterparts in permanent employment; although the former, indeed, are less likely to participate in formal training activities.

These results account for the endogeneity of the selection into temporary contracts and for the binary nature of the endogenous regressor. Results are robust to changes in our model specification and more efficient in comparison with alternative 2SLS specifications. We conclude that the ATE of temporary contracts on the intensity of informal learning on-the-job is positive and about 0.17 of a standard deviation in the OECD countries included in our sample. This result is substantial if we consider that it 
is about the same as the impact of ten years of schooling. Consistent with human capital theory, we also found that workers' informal learning intensity decreases with age and tenure. Conversely, it increases with years of education, actual working hours, elaborate learning and undereducation. The groups that benefit most are individuals employed in high-skilled occupations and larger firms.

On the assumption that full-time male workers prefer permanent contracts (Booth et al., 2002; Jahn and Bentzen, 2012); we hypothesise that flex workforce would rationally invest more in informal learning to increase their possibilities of transition towards more stable employment. Thus, it would be expected that those individuals with positive prospects of upward mobility in the labour market would be more likely to invest more in informal learning on-the-job. This may be incentivised by different attributes of informal learning in contrast to training, primarily the lower opportunity costs (De Grip and Smits, 2012; Destré et al., 2008).

Research on the 'stepping stone' effects of temporary employment is in line with this hypothesis. These studies often evoke the idea that transition odds most probably increase with the improvement of human capital, work experience and general labour skills while being on assignment (Abraham, 1990; Autor, 2001; Booth et al., 2002; Cockx \& Picchio, 2012; de Graaf-Zijl et al., 2011; Gagliarducci, 2005; Jahn and Rosholm, 2014; Jahn and Pozzoli, 2013). Human capital investments in on-the-job learning are seen as the main mechanism through which temporary employment offers a path to permanent jobs.

Hence, temporary workers' expectations of later promotion in the labour market may be responsible for the stronger incentives to invest in informal learning. Flex workforce may perceive more intense learning as a profitable investment for job career development. These decisions probably depend on the manner in which uncertainty affects the returns to investments in relation to possible changes in the future, such as the wage gains of shifting to a better job. Weiss (1986) provides some theoretical support for this explanation. He states that if the returns to learning are affected by uncertainty, supplementary investments in human capital become a way of hedging against risk. In addition, if these investments are positively influenced by a decreased discount rate because the future becomes more important, incentives for self-investment increase and give rise to capital accumulation until finding a job that offers better stability conditions.

This has two important implications. First, if optimal human capital investments decline over the lifecycle by the search for a proper match or a better job, the learning intensity in temporary employment is likely to be higher, as we actually found, the earlier in the working life and/or the earlier the job occurs. Second, accepting a temporary job that might pay less initially but involves 
higher learning potential ${ }^{32}$ can be a good strategy for workers in their early careers, to maximise lifetime income. That is because such jobs are more likely to be a stepping-stone for occupational mobility within or across firms (de Grip and Smits, 2012; Sicherman and Galor, 1990).

In addition, this paper shows evidence for complementarity between job-related training and informal learning for both temporary and permanent employees. This suggests that the higher informal learning investment of temporary workers does not substitute for the lack of formal training at the individual level. This complementarity may arise because of the self-productivity of human capital, so that human capital accumulated through training is useful for informal learning on-the-job (Nelen and De Grip, 2009). It can also be associated to higher previous investments in formal schooling, which not only provide higher skills, but may also increase a worker's learning capacity. Since more educated individuals are more likely of greater ability, they are more efficient learners who also tend to invest more in job training and informal learning (Mincer, 1994; Rosen, 1972). One initial repercussion of this complementarity is that studies on returns to job training might have overestimated results as they usually attribute all the benefits of skill acquisition to workers' participation in training without taking into consideration the informal learning costs.

A second implication is that the policy objective of promoting flexicurity in several OECD countries is still a challenge regarding the learning potential of temporary jobs. If flexible work is taken by people against unemployment in search for further individual promotion into the labour market, it would be on the condition that they can continue learning. Since human capital in the workplace is accumulated through both training and informal learning and they complement each other, our results imply that there are at least two easily differentiable kinds of flex employment in terms of learning content. First, 'good' temporary jobs with plenty opportunities for training and informal learning, likely involving positive career expectations of upward mobility and, second, 'bad' temporary jobs in which there are none or very few possibilities to participate in training and informal learning activities that would cause most workers to be trapped in precarious employment. The latter group is in a disadvantaged situation to build on skills for their job careers. Moreover, such jobs limit the adaptability of the flexible part of the workforce that is presumed to play a key role in economic and labour market adjustment processes.

Thus, our results suggest that labour inequality among OECD countries should also be investigated within temporary employment because of the fragmentation between low and high learning content jobs. The important policy conclusion from our work is then that temporary jobs need not be dead-end jobs. Instead, by offering sufficient opportunities to learn on the job, they could function as a stepping-

32. In this respect, the job’s learning potential can refer to informal learning as well as to formal training participation. 
stone towards more stable employment. As indicated by the Cedefop (2011) and the European Commission (2010b), the flexicurity concept assumes that it is the worker who needs support for a successful transition either with the same or with another employer. Thus, formal and informal investments in human capital need to be provided and complemented in the workplace to strengthen the employability of temporary workers and to facilitate the adjustment of the economy. All this implies further efforts in research and policy responses towards the balance between flexibility and security sought by the OECD countries. 


\section{REFERENCES}

Abraham, K. (1990) Restructuring the employment relationship: The growth of market-mediated work arrangements. In Abraham, K. and McKersie, R. (Eds.), New developments in the labour market: Toward a new institutional Paradigm. Cambridge, MA, MIT Press, 85-119.

Acemoglu, D. and. Pischke J. (1999) Beyong Becker: Training in imperfect Labour Markets. The Economic Journal 109: 112-142.

Akgündüz, Y., and Van Huizen, T. (2013) Training in Two-Tier Labour Markets: The Role of Job Match Quality. Working paper, Utrecht University School of Economics.

Albert, C., García-Serrano, C. and Hernanz, V. (2010) On-the-job training in Europe: Determinants and wage returns. International Labour Review 149(3): 315-341.

Angrist, J. and Pischke J. (2009) Mostly Harmless Econometrics: An Empiricist's Companion. Princeton, Princeton University Press.

Arrow, K. (1962) The economic implications of learning-by-doing. Review of Economic Studies 24(3): 155-173.

Arulampalam, W. and Booth, A. (1998) Training and Labour Market Flexibility: Is there a Trade-off? The British Journal of Industrial Relations 36(4): 521-536.

Arulampalam, W., Booth, A. and Bryan, M. (2004) Training in Europe. Journal of the European Economic Association 2(2-3): 346-360.

Atkinson, A. (1998). Exclusion, Employment and Opportunity. CASE Working Paper, Centre for Analysis of Social Exclusion, London School of Economics.

Autor, D. (2001) Why Do Temporary Help Firms Provide Free General Skills Training? The Quarterly Journal of Economics 116 (4): 1409-1448.

Belzil C. and Leonardi, M. (2007) Can Risk Aversion Explain Schooling Attainments? Evidence from Italy. Labour Economics 14 (6): 957-970.

Ben-Porath, Y. (1967). The Production of Human Capital and the Life Cycle of Earnings. Journal of Political Economy 75: 352-365.

Berton, F. and Garibaldi, P. (2012) Workers and Firms Sorting into Temporary Jobs. The Economic Journal 122 (562): 125 - 154.

Berton, F., Devicienti, F. and Pacelli, L. (2011) Are temporary jobs a port of entry into permanent employment?: Evidence from matched employer-employee. International Journal of Manpower 32(8): 879 - 899.

Billet, S. (2001) Learning in the workplace: Strategies for effective practice. Sydney: Allen and Unwin.

Billet, S. (2008) Emerging Perspectives on Workplace Learning. In Billet, S., Harteis, C., and Eteläpelto, A. (Eds.), Emerging Perspectives of Workplace Learning. Rotterdam, The Netherlands, Sense, 1-15.

Blundell, R., Dearden, L., Meghir, C. and Sianesi, B. (1999) Human Capital Investment: The Returns from Education and Training to the Individual, the Firm and the Economy. Fiscal Studies 20 (1): 1- 23.

Booth, A. and Bryan, M. (2004) Training in Europe. Journal of the European Economic Association 2(2-3): 346-360.

Booth, A., Francesconi, M. and Frank, J. (2002) Temporary jobs: Stepping stones or dead ends? Economic Journal 112: 585-606.

Cedefop (2011) Learning while working. Success stories on workplace learning in Europe. Luxembourg: Publications Office of the European Union, The European Centre for the Development of Vocational Training.

Cockx, B., and M. Picchio (2012). Are short-lived jobs stepping stones to long-lasting jobs? Oxford Bulletin of Economics and Statistics 74(5): 646-675.

Comi, S. and Grasseni, M. (2012) Are Temporary Workers Discriminated Against? Evidence from Europe. The Manchester School 80(1): 28-50.

Cutulli, G. and Guetto, R. (2013) Fixed-Term Contracts, Economic Conjuncture, and Training Opportunities: A Comparative Analysis across European Labour Markets. European Sociological Review 29 (3): 616-629.

Destré, G, Lévy-Garboua, L. and Sollogoub, M. (2008) Learning from experience or learning from others? Inferring informal training from a human capital earnings function with matched employer-employee data. The Journal of Socio-Economics 37: 919-938. 
De Graaf-Zijl, M., van den Berg, G. and Heyma, A. (2011) Stepping stones for the unemployed: the effect of temporary jobs on the duration until (regular) work. Journal of Population Economics 24(1): 107-139.

De Grip, A. and Smits, W. (2012) What affects lifelong learning of scientists and engineers? International Journal of Manpower 33(5): 583 - 597.

Dekker, R. (2007). Non-Standard Employment and Mobility in the Dutch, German and British Labour Market. Ridderkerk: Ridderprint.

Engellandta, A. and Riphahn, R. (2005) Temporary contracts and employee effort. Labour Economics 12(3): 281-299.

European Commission (2013) Flexicurity in Europe. Administrative Agreement. Final Report. Luxembourg: Publications Office of the European Union.

(2010) Employment in Europe 2010. Luxembourg: Publications Office of the European Union.

(2010b). Changing patterns of working, learning and career development across Europe. Final Report. Luxembourg: Publications Office of the European Union.

(2007) Towards Common Principles of Flexicurity: More and better jobs through flexibility and security. Luxembourg: Publications Office of the European Union.

(2003) Employment in Europe. Luxembourg: Publications Office of the European Union.

Faccini, R. (2014) Reassessing Labour Market Reforms: Temporary Contracts as a Screening Device. The Economic Journal 124 (575): 167-200.

Gagliarducci, S. (2005) The dynamics of repeated temporary jobs. Labour Economics 12 (4): 429 - 448.

Gebel, M. (2013) Is a Temporary Job Better Than Unemployment? A Cross-country Comparison Based on British, German, and Swiss Panel Data. Journal of Applied Social Science Studies 133(2): 143-155.

Givord, P., and Wilner, L. (2014) When Does The Stepping-Stone Work? Fixed-Term Contracts versus Temporary Agency Work In Changing Economic Conditions. Journal Of Applied Econometrics DOI: 10.1002/jae.

Greene, W. (2012) Econometric Analysis, seventh edition. New York, Pearson Education.

Grund, C. and Martin, J. (2012) Determinants of further training - evidence for Germany. The International Journal of Human Resource Management 23(17): 3536-3558.

Heckman, J. (1978) Dummy Endogenous Variables in a Simultaneous Equation System. Econometrica 46(4): 931-959.

(1976) A Life-Cycle Model of Earnings, Learning, and Consumption. Journal of Political Economy 84 (4): 11-44.

Heckman, J. and Navarro-Lozano, S. (2004) Using Matching, Instrumental Variables, and Control Functions to Estimate Economic Choice Models. The Review of Economics and Statistics 86(1): 30-57.

Heckman, J., Tobias, J. and Vytlacil, E. (2001) Four Parameters of Interest in the Evaluation of Social Programs. Southern Economic Journal 68(2): 210-223.

Heckman, J. and Vytlacil, E. (2005) Structural Equations, Treatment Effects, and Econometric Policy Evaluation. Econometrica 73(3): 669-738

(1999). Local instrumental variables and latent variable models for identifying and bounding treatment effects. Proceedings of the National Academy of Sciences 96: 4730-4734.

ILO (2010) The impact of the economic and financial crisis on youth employment: Measures for labour market recovery in the European Union, Canada and the United States. Employment Working Paper No. 70. International Labour Office, Youth Employment Programme. Geneva: ILO.

Imbens, G. and Wooldridge, J. (2009) Recent Developments in the Econometrics of Program Evaluation. Journal of Economic Literature 47(1): 5-86.

Jackson, C. (2012) Match quality, worker productivity, and worker mobility: Direct evidence from teachers. The Review of Economics and Statistics 95(4): 1096-1116.

Jahn, E. and Bentzen, J. (2012) What Drives the Demand for Temporary Agency Workers? LABOUR 26 (3): 341-355. 
Jahn, E. and Pozzoli, D. (2013) The pay gap of temporary agency workers - Does the temporary sector experience pay off? Labour Economics 24: 48-57.

Jahn, E. and Rosholm, M. (2014) Looking beyond the bridge: The effect of temporary agency employment on labor market outcomes. European Economic Review 65: 108-125.

Kahn, L. (2010) Employment protection reforms, employment and the incidence of temporary jobs in Europe: 1996-2001. Labour Economics 17: 1-15.

Keogh, H. (2009). The state and development of adult learning and education in Europe, North America and Israel. Regional Synthesis Report. Hamburg: UNESCO Institute for Lifelong Learning.

Kirby, J., Knapper, C., Evans, C., Carty, A., and Gadula, C. (2003). Approaches to learning at work and workplace climate. International Journal of Training and Development 7(1): 31-52.

Killingsworth, M. (1982) "Learning-by-doing" and "Investment in Training": A Synthesis of Two "Rival" Models of the Life Cycle. The Review of Economic Studies 49 (2): 263-271.

Koopmans, H., Doornbos, A., and Eekelen, I. (2006). Learning in interactive work situations: It takes two to tango; why not invite both partners to dance? Human Resource Development Quarterly 17: 135-158.

Loewenstein, M. And Spletzer, J. (1997) Delayed Formal On-The-Job Training. Industrial and Labor Relations Review 51(1): 82-99.

Loh, E. (1994): Employment probation as a sorting mechanism. Industrial and Labor Relations Review 47 (3): 471-486.

Maddala, G. (1983) Limited-Dependent and Qualitative Variables in Econometrics (Econometric Society Monographs, 3) (Kindle Locations 5759-5766). Cambridge University Press. Kindle Edition.

Marsick, V. (2009). Toward a unifying framework to support informal learning theory, research and practice. Journal of Workplace Learning 21(4): 265-275.

Marsick, V., Watkins, K., Callahan, M., and Volpe, M. (2009). Informal and incidental learning in the workplace. In Smith, M. and DeFrates-Densch, N. (Eds.), Handbook of research on adult learning and development. New York, NY: Routledge, 570-599.

Maurer, T. and Weiss, E. (2010) Continuous Learning Skill Demands: Associations with Managerial Job Content, Age, and Experience. Journal of Business and Psychology 25(1): 1-13.

Miranda, A and Rabe-Hesketh, S. (2006) Maximum likelihood estimation of endogenous switching and sample selection models for binary, count, and ordinal variables. Stata Journal 6 (3): 285-308.

Mincer, J. (1994) The Production of Human Capital and the Lifecycle of Earnings: Variations on a theme. NBER Working paper series No. 4838. Massachusetts, National Bureau of Economic Research.

(1974). Schooling, Experience and Earnings. New York: Columbia University Press.

(1968) Job Training, Wage Growth and Labour Turnover. NBER Working paper series No. 2690. Massachusetts, National Bureau of Economic Research.

Mincer, J. and Jovanovic, B. (1981) Labour mobility and wages. In: Rosen, S. (Ed.), Studies in Labour Markets. Chicago, Chicago University Press, 21-64.

Nelen, A. and De Grip, A. (2009) Why do Part-Time Workers invest less in Human Capital than Full Timers? LABOUR 23(s1): 61-83.

Newey, W. (1990) Semiparametric Efficiency Bounds. Journal of Applied Econometrics 5: 99-135.

O’Connell, P. and Byrne, D. (2010). The determinants and effects of training at work: bringing the workplace back in. European Sociological Review, DOI: 10.1093/esr/jcq063.

OECD (2014) OECD Employment Outlook 2014, OECD Publishing. (2014b) Technical Report of the Survey of Adult Skills, Reader’s Companion. OECD Publishing. (2010) Recognising Non-Formal And Informal Learning Outcomes, Policies and Practices. OECD Publishing. (2006) OECD Employment Outlook 2006. OECD Publishing. (2004) OECD Employment Outlook 2004. OECD Publishing.

Pfeifer, C. (2014) A Note on Dual Internal Labor Markets and Wages of Temporary Workers: Evidence from Linked-Employer-Employee Data. Journal of Labor Research 35 2): 133-142. 
Quinones, M., Ford, J., and Teachout, M. (1995). The relationship between work experience and job performance: A conceptual and meta-analytic review. Personnel Psychology 48: 887-910.

Rabe-Hesketha, S., Skrondalb, A. and Picklesc, A. (2005) Maximum likelihood estimation of limited and discrete dependent variable models with nested random effects. Journal of Econometrics 128: 301-323.

Rosen, S. (1972) Learning and Experience in the Labour Market. Journal of Human Resources 7: 326-342.

Sala, H., Silva, J. and Toledo, M. (2012) Flexibility at the Margin and Labor Market Volatility in OECD Countries. The Scandinavian Journal of Economics 114(3): 991-1017.

Sicherman, N. and Galor, O. (1990). A theory of career mobility. Journal of Political Economy 98(1): 169-92.

Steijn, B., Need, A. and Gesthuizen, M. (2006) Well Begun, Half Done? Long-Term Effects of Labour Market Entry in the Netherlands, 1950-2000. Work, Employment and Society 20(3): 453-72.

Stevens, M. (1994). An investment model for the supply of training by employers. Economic Journal 104(424): 556-570.

Straka, G. (2000). Conditions promoting self-directed learning at the workplace. Human Resources Development International 3(2): 241-251.

Svensson, L., Ellström, P. and Aberg, C. (2004). Integrating formal and informal learning at work. Journal of Workplace Learning 16(7/8): 479-492.

Tannenbaum, S., Beard, R., McNall, L., and Salas, E. (2010). Informal learning and development in organizations. In Kozlowski, S. and Salas, E. (Eds.), Learning, training, and development in organizations. New York: Routledge, 303-332.

Tesluk, P., and Jacobs, R. (1998). Toward an integrated model of work experience. Personnel Psychology 51: 321-355.

Weiss, Y. (1986) The determination of life cycle earnings: A survey. In Ashenfelter O., Layard, R. and Card, D. (Eds.) Handbook of Labor Economics. Elsevier, doi:10.1016/S1573-4463(86)01014-3, 603-640.

Wooldridge, J. (2003). Further results on instrumental variables estimation of average treatment effects in the correlated random coefficient model. Economics Letters 79: 185-191.

Wooldridge, J. (2010). Econometric Analysis of Cross Section and Panel Data, second edition. Cambridge, MA: MIT Press. 
Table 1. Sample description

\begin{tabular}{|c|c|c|c|c|c|c|c|c|c|}
\hline COUNTRY & TOTAL OBS. & FINAL SAMPLE & $\%$ & PERMANENT & $\%$ & $\%$ OECD* & TEMP & $\%$ & $\%$ OECD* \\
\hline 1 Austria & 2,530 & 1,249 & 4.9 & 1,171 & 93.8 & 90.7 & 78 & 6.2 & 9.3 \\
\hline 2 Belgium & 2,700 & 1,196 & 4.7 & 1,144 & 95.7 & 92.9 & 52 & 4.3 & 7.1 \\
\hline 3 Canada & 12,728 & 1,164 & 4.6 & 1,052 & 90.4 & 87.0 & 112 & 9.6 & 13.0 \\
\hline 4 Czech Republic & 2,769 & 1,176 & 4.6 & 1,013 & 86.1 & 92.6 & 163 & 13.9 & 7.4 \\
\hline 5 Denmark & 4,560 & 1,743 & 6.9 & 1,634 & 93.7 & 92.2 & 109 & 6.3 & 7.8 \\
\hline 6 Estonia & 3,464 & 1,577 & 6.2 & 1,434 & 90.9 & 95.3 & 143 & 9.1 & 4.7 \\
\hline 7 Finland & 2,757 & 1,259 & 5.0 & 1,157 & 91.9 & 87.2 & 102 & 8.1 & 12.8 \\
\hline 8 France & 3,430 & 1,616 & 6.4 & 1,477 & 91.4 & 85.6 & 139 & 8.6 & 14.4 \\
\hline 9 Germany & 2,676 & 1,345 & 5.3 & 1,212 & 90.1 & 86.1 & 133 & 9.9 & 13.9 \\
\hline 10 Ireland & 2,744 & 931 & 3.7 & 801 & 86.0 & 90.1 & 130 & 14.0 & 9.9 \\
\hline 11 Italy & 2,235 & 925 & 3.6 & 835 & 90.3 & 87.1 & 90 & 9.7 & 12.9 \\
\hline 12 Japan & 2,517 & 1,494 & 5.9 & 1,332 & 89.2 & 91.4 & 162 & 10.8 & 8.6 \\
\hline 13 Korea & 3,102 & 1,162 & 4.6 & 905 & 77.9 & 78.9 & 257 & 22.1 & 21.1 \\
\hline 14 Netherlands & 2,546 & 1,168 & 4.6 & 1,032 & 88.4 & 81.4 & 136 & 11.6 & 18.6 \\
\hline 15 Norway & 2,655 & 1,147 & 4.5 & 1,090 & 95.0 & 93.3 & 57 & 5.0 & 6.7 \\
\hline 16 Poland & 4,733 & 1,495 & 5.9 & 923 & 61.7 & 72.6 & 572 & 38.3 & 27.4 \\
\hline 17 Slovak Republic & 2,706 & 1,183 & 4.7 & 1,014 & 85.7 & 93.6 & 169 & 14.3 & 6.4 \\
\hline 18 Spain & 2,964 & 1,061 & 4.2 & 894 & 84.3 & 78.0 & 167 & 15.7 & 22.0 \\
\hline 19 Sweden & 2,253 & 1,156 & 4.6 & 1,081 & 93.5 & 85.7 & 75 & 6.5 & 14.3 \\
\hline 20 United Kingdom & 3,737 & 1,319 & 5.2 & 1,172 & 88.9 & 94.1 & 147 & 11.1 & 5.9 \\
\hline Total & 69,806 & 25,366 & 100 & 22,373 & 88.2 & 87.8 & 2,993 & 11.8 & 12.2 \\
\hline
\end{tabular}

* OECD statistics 2012 
Table 2. Summary statistics

\begin{tabular}{|c|c|c|c|c|c|c|}
\hline \multirow{2}{*}{ Variable } & \multicolumn{2}{|c|}{ Permanent } & \multicolumn{2}{|c|}{ Temporary } & \multicolumn{2}{|c|}{ All } \\
\hline & Mean & Std. Dev. & Mean & Std. Dev. & Min & Max \\
\hline Informal learning intensity (standarised index) & -0.03 & 0.98 & 0.03 & 1.09 & -3.39 & 2.05 \\
\hline Informal learning incidence & 0.98 & 0.14 & 0.97 & 0.17 & 0 & 1 \\
\hline Training (participation)* & 0.52 & 0.50 & 0.39 & 0.49 & 0 & 1 \\
\hline Age & 42.08 & 11.11 & 36.04 & 12.83 & 17 & 65 \\
\hline Years of education & 13.30 & 2.89 & 12.93 & 3.09 & 3 & 22 \\
\hline Work experience (years) & 21.31 & 11.67 & 14.59 & 12.59 & 0 & 47 \\
\hline Overeducated & 0.23 & 0.42 & 0.30 & 0.46 & 0 & 1 \\
\hline Undereducated & 0.07 & 0.26 & 0.05 & 0.23 & 0 & 1 \\
\hline Elaborate learning (standardised index) & -0.02 & 1.00 & -0.04 & 1.09 & -6.89 & 8.86 \\
\hline Tenure (years) & 11.90 & 10.26 & 4.44 & 7.33 & 0 & 51 \\
\hline Weekly working hours & 42.52 & 7.28 & 42.58 & 8.37 & 35 & 60 \\
\hline Firm size 1-10 & 0.20 & 0.40 & 0.24 & 0.43 & 0 & 1 \\
\hline Firm size $11-50$ & 0.30 & 0.46 & 0.32 & 0.47 & 0 & 1 \\
\hline Firm size 51 -250 & 0.26 & 0.44 & 0.24 & 0.43 & 0 & 1 \\
\hline Firm size $251-1000$ & 0.14 & 0.35 & 0.12 & 0.33 & 0 & 1 \\
\hline Firm size $>1000$ & 0.10 & 0.30 & 0.07 & 0.25 & 0 & 1 \\
\hline \multicolumn{7}{|l|}{ Occupation } \\
\hline Managers & 0.10 & 0.30 & 0.05 & 0.21 & 0 & 1 \\
\hline Professionals & 0.18 & 0.39 & 0.15 & 0.36 & 0 & 1 \\
\hline Technicians & 0.18 & 0.39 & 0.11 & 0.31 & 0 & 1 \\
\hline Clerks & 0.07 & 0.25 & 0.08 & 0.27 & 0 & 1 \\
\hline Services and sales workers & 0.09 & 0.28 & 0.11 & 0.32 & 0 & 1 \\
\hline Skilled agricultural and fishery workers & 0.01 & 0.10 & 0.02 & 0.13 & 0 & 1 \\
\hline Craft workers & 0.18 & 0.39 & 0.21 & 0.41 & 0 & 1 \\
\hline Operators & 0.13 & 0.34 & 0.17 & 0.37 & 0 & 1 \\
\hline Elementary occupations & 0.05 & 0.22 & 0.11 & 0.31 & 0 & 1 \\
\hline \multicolumn{7}{|l|}{ Industry } \\
\hline Agriculture, forestry and fishing & 0.02 & 0.13 & 0.03 & 0.16 & 0 & 1 \\
\hline Manufacturing & 0.30 & 0.46 & 0.30 & 0.46 & 0 & 1 \\
\hline Construction & 0.11 & 0.31 & 0.14 & 0.34 & 0 & 1 \\
\hline Sales, transportation, accomodation and food services & 0.22 & 0.42 & 0.20 & 0.40 & 0 & 1 \\
\hline Information and communication & 0.05 & 0.21 & 0.03 & 0.16 & 0 & 1 \\
\hline Finance & 0.03 & 0.18 & 0.02 & 0.13 & 0 & 1 \\
\hline Real estate & 0.01 & 0.09 & 0.01 & 0.10 & 0 & 1 \\
\hline Professional, technical and administration services & 0.08 & 0.26 & 0.09 & 0.29 & 0 & 1 \\
\hline Public administration, education and health & 0.17 & 0.38 & 0.15 & 0.36 & 0 & 1 \\
\hline Other services & 0.02 & 0.15 & 0.04 & 0.19 & 0 & 1 \\
\hline Observations & 22,3 & & 2,99 & & 25 , & \\
\hline \multicolumn{7}{|l|}{ Selection instrument } \\
\hline Unemployment rate (by country and age groups) & 0.07 & 0.04 & 0.10 & 0.06 & 0 & 0.57 \\
\hline Unemployment rate (standardised) & -0.07 & 0.90 & 0.55 & 1.46 & -1.25 & 10.63 \\
\hline EPL regular employment (standardised) & 0.03 & 0.98 & 0.10 & 0.90 & -1.88 & 1.98 \\
\hline
\end{tabular}

* For this particular variable we have fewer observations (22447). It is due to lower response rate and the exclusion of respondents who followed training while being unemployed. 
Table 3. Estimations of on-the-job informal learning intensity

\begin{tabular}{|c|c|c|c|c|c|}
\hline & $\begin{array}{l}\text { (1) } \\
\text { OLS }\end{array}$ & $\begin{array}{c}(2) \\
\text { 2SLS } \\
\text { (1 instrument) }\end{array}$ & $\begin{array}{c}\text { (3) } \\
\text { 2SLS } \\
\text { (3 instruments) } \\
\end{array}$ & $\begin{array}{c}\text { (4) } \\
\text { CF-ML } \\
\text { (1 instrument) }\end{array}$ & $\begin{array}{c}\text { (5) } \\
\text { CF-ML } \\
\text { (3 instruments) } \\
\end{array}$ \\
\hline \multicolumn{6}{|l|}{ Informal Learning Equation } \\
\hline Temporary contract & $\begin{array}{l}0.0953^{* * *} \\
(0.0280)\end{array}$ & $\begin{array}{l}1.5036^{* * *} \\
(0.3995)\end{array}$ & $\begin{array}{c}0.9877^{* * *} \\
(0.2753)\end{array}$ & $\begin{array}{c}0.1667^{* * *} \\
(0.0502)\end{array}$ & $\begin{array}{l}0.1698^{* * *} \\
(0.0501)\end{array}$ \\
\hline Age & $\begin{array}{c}-0.0271^{* * * *} \\
(0.0050)\end{array}$ & $\begin{array}{c}0.0156 \\
(0.0120)\end{array}$ & $\begin{array}{c}0.0054 \\
(0.0116)\end{array}$ & $\begin{array}{c}-0.0249^{* * * *} \\
(0.0049)\end{array}$ & $\begin{array}{c}-0.0248^{* * * *} \\
(0.0050)\end{array}$ \\
\hline Age $^{2}$ & $\begin{array}{l}0.0002^{* * *} \\
(0.0001)\end{array}$ & $\begin{array}{c}-0.0003^{* *} \\
(0.0001)\end{array}$ & $\begin{array}{l}-0.0002 \\
(0.0001)\end{array}$ & $\begin{array}{l}0.0002^{* * *} \\
(0.0001)\end{array}$ & $\begin{array}{l}0.0002^{* * *} \\
(0.0001)\end{array}$ \\
\hline Years of education & $\begin{array}{l}0.0155^{* * *} \\
(0.0033)\end{array}$ & $\begin{array}{l}0.0204^{* * *} \\
(0.0050)\end{array}$ & $\begin{array}{l}0.0193^{* * *} \\
(0.0048)\end{array}$ & $\begin{array}{l}0.0156^{* * *} \\
(0.0034)\end{array}$ & $\begin{array}{l}0.0156^{* * *} \\
(0.0034)\end{array}$ \\
\hline Overeducated & $\begin{array}{c}-0.1045^{* * * *} \\
(0.0162)\end{array}$ & $\begin{array}{c}-0.1284^{* * * *} \\
(0.0202)\end{array}$ & $\begin{array}{c}-0.1227^{* * *} \\
(0.0194)\end{array}$ & $\begin{array}{c}-0.1046^{* * * *} \\
(0.0161)\end{array}$ & $\begin{array}{c}-0.1046^{* * *} \\
(0.0161)\end{array}$ \\
\hline Undereducated & $\begin{array}{l}0.1544^{* * * *} \\
(0.0278)\end{array}$ & $\begin{array}{l}0.1565^{* * *} \\
(0.0268)\end{array}$ & $\begin{array}{l}0.1560^{* * * *} \\
(0.0267)\end{array}$ & $\begin{array}{l}0.1543^{* * * *} \\
(0.0277)\end{array}$ & $\begin{array}{l}0.1543^{* * *} \\
(0.0277)\end{array}$ \\
\hline Working hours & $\begin{array}{l}0.0068^{* * * *} \\
(0.0012)\end{array}$ & $\begin{array}{l}0.0075^{* * *} \\
(0.0013)\end{array}$ & $\begin{array}{l}0.0074^{* * * *} \\
(0.0013)\end{array}$ & $\begin{array}{c}0.0067^{* * * *} \\
(0.0012)\end{array}$ & $\begin{array}{l}0.0067^{* * *} \\
(0.0012)\end{array}$ \\
\hline Tenure & $\begin{array}{c}-0.0031^{* * *} \\
(0.0009)\end{array}$ & $\begin{array}{l}0.0063^{* *} \\
(0.0030)\end{array}$ & $\begin{array}{c}0.0041 \\
(0.0029)\end{array}$ & $\begin{array}{c}-0.0031^{* * *} \\
(0.0009)\end{array}$ & $\begin{array}{c}-0.0031^{* * *} \\
(0.0009)\end{array}$ \\
\hline Elaborate learning & $\begin{array}{l}0.2041^{* * *} \\
(0.0148)\end{array}$ & $\begin{array}{l}0.2042^{* * *} \\
(0.0149)\end{array}$ & $\begin{array}{l}0.2042^{* * * *} \\
(0.0147)\end{array}$ & $\begin{array}{l}0.2040^{* * * *} \\
(0.0148)\end{array}$ & $\begin{array}{l}0.2040^{* * *} \\
(0.0148)\end{array}$ \\
\hline _cons & $\begin{array}{l}-0.1483 \\
(0.1209)\end{array}$ & $\begin{array}{c}-1.4037^{* * * *} \\
(0.3553)\end{array}$ & $\begin{array}{c}-0.6646^{* * *} \\
(0.1691)\end{array}$ & $\begin{array}{l}-0.2095 \\
(0.1288)\end{array}$ & $\begin{array}{l}-0.2125 \\
(0.1293)\end{array}$ \\
\hline Other controls & yes & yes & yes & yes & yes \\
\hline Country dummies & yes & yes & yes & yes & yes \\
\hline Temporary Contract Equation & & & & $A M E$ & $A M E$ \\
\hline Unemployment & & $\begin{array}{c}0.0467^{* * *} \\
(0.0057)\end{array}$ & $\begin{array}{c}0.0479^{* * *} \\
(0.0075)\end{array}$ & $\begin{array}{l}0.0160^{* * *} \\
(0.0056)\end{array}$ & $\begin{array}{c}0.0239^{* * *} \\
(0.0073)\end{array}$ \\
\hline Unemployment *EPL moderate & & & $\begin{array}{c}0.0016 \\
(0.0083)\end{array}$ & & $\begin{array}{c}-0.0117 \\
(0.0065)\end{array}$ \\
\hline Unemployment * EPL low & & & $\begin{array}{c}-0.0713^{* * *} \\
(0.0135)\end{array}$ & & $\begin{array}{c}-0.0625^{* * *} \\
(0.0078)\end{array}$ \\
\hline Age & & $\begin{array}{c}-0.0180^{* * * *} \\
(0.0019)\end{array}$ & $\begin{array}{c}-0.0192^{* * *} \\
(0.0019)\end{array}$ & $\begin{array}{c}-0.0203^{* * *} \\
(0.0023)\end{array}$ & $\begin{array}{c}-0.0213^{* * *} \\
(0.0019)\end{array}$ \\
\hline $\mathrm{Age}^{2}$ & & $\begin{array}{l}0.0002^{* * *} \\
(0.0000)\end{array}$ & $\begin{array}{l}0.0002^{* * *} \\
(0.0000)\end{array}$ & $\begin{array}{c}0.0002^{* * *} \\
(0.0000)\end{array}$ & $\begin{array}{l}0.0002^{* * *} \\
(0.0000)\end{array}$ \\
\hline Years of education & & $\begin{array}{c}-0.0035^{* * * *} \\
(0.0009)\end{array}$ & $\begin{array}{c}-0.0035^{* * *} \\
(0.0009)\end{array}$ & $\begin{array}{l}-0.0010 \\
(0.0017)\end{array}$ & $\begin{array}{l}-0.0010 \\
(0.0017)\end{array}$ \\
\hline Overeducated & & $\begin{array}{l}0.0169^{* * *} \\
(0.0048)\end{array}$ & $\begin{array}{l}0.0167^{* * *} \\
(0.0048)\end{array}$ & & \\
\hline Undereducated & & $\begin{array}{c}-0.0018 \\
(0.0068)\end{array}$ & $\begin{array}{c}-0.0010 \\
(0.0068)\end{array}$ & & \\
\hline Working hours & & $\begin{array}{l}-0.0006^{*} \\
(0.0003)\end{array}$ & $\begin{array}{c}-0.0006^{* *} \\
(0.0003)\end{array}$ & & \\
\hline Tenure & & $\begin{array}{c}-0.0067^{* * * *} \\
(0.0002)\end{array}$ & $\begin{array}{c}-0.0067^{* * *} \\
(0.0002)\end{array}$ & & \\
\hline Elaborate learning & & $\begin{array}{c}0.0005 \\
(0.0027)\end{array}$ & $\begin{array}{c}0.0005 \\
(0.0027)\end{array}$ & $\begin{array}{c}0.0027 \\
(0.0023)\end{array}$ & $\begin{array}{c}0.0028 \\
(0.0023)\end{array}$ \\
\hline Other controls & & yes & yes & yes & yes \\
\hline Country dummies & & yes & yes & yes & yes \\
\hline First-stage Tests & & $\mathrm{F}(49,25316)$ & $\mathrm{F}(51,25314)$ & Wald chi2(45) & Wald chi2(47) \\
\hline $\begin{array}{l}\text { Adj. } R^{2} \text { First-stage } \\
\text { athrho }\end{array}$ & & $\begin{array}{c}=58.60 \\
0.1400\end{array}$ & $\begin{array}{l}=56.97 \\
0.1413\end{array}$ & $\begin{array}{c}=2243.9 \\
0.1305 \\
-0.0746^{* * * *} \\
(0.0223)\end{array}$ & $\begin{array}{c}=2245.6 \\
0.1325 \\
-0.0774^{* * *} \\
(0.0219)\end{array}$ \\
\hline Insigma & & & & $\begin{array}{c}-0.1033^{* * * *} \\
(0.0351)\end{array}$ & $\begin{array}{c}-0.1055^{* * *} \\
(0.0351)\end{array}$ \\
\hline $\begin{array}{l}\text { IV Test of endogeneity / } \\
\text { Wald test of indep. Eqns. }(\text { rho }=0)\end{array}$ & & $\begin{array}{l}\mathrm{F}(1,19)=16.0 \\
(p=0.0008)\end{array}$ & $\begin{array}{c}\mathrm{F}(1,19)=9.47 \\
(p=0.0062)\end{array}$ & $\begin{array}{c}\text { Chi2 }(1)=4.72 \\
(p=0.0299)\end{array}$ & $\begin{array}{c}\text { Chi2 }(1)=5.60 \\
(p=0.0179)\end{array}$ \\
\hline 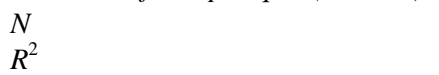 & $\begin{array}{l}25,366 \\
0.1744\end{array}$ & $\begin{array}{l}25,366 \\
0.0798\end{array}$ & $\begin{array}{l}25,366 \\
0.1024\end{array}$ & 25,366 & 25,366 \\
\hline
\end{tabular}


Table 4. Estimations of on-the-job informal learning intensity with heterogeneous employees

\begin{tabular}{|c|c|c|c|c|}
\hline & $\begin{array}{c}(1) \\
\text { CF-ML } \\
\text { (1 instrument) }\end{array}$ & $\begin{array}{c}\text { Difference } \\
\text { Permanent and } \\
\text { Temporary contract }\end{array}$ & $\begin{array}{c}\text { (2) } \\
\text { CF-ML } \\
\text { (3 instruments) }\end{array}$ & $\begin{array}{c}\text { Difference } \\
\text { Permanent and } \\
\text { Temporary contract }\end{array}$ \\
\hline ATE & $\begin{array}{l}\mathbf{0 . 1 2 5 5 ^ { * * }} \\
(0.0500)\end{array}$ & & $\begin{array}{l}\mathbf{0 . 1 2 9 2}^{* *} \\
(0.0517)\end{array}$ & \\
\hline$A T T$ & $\begin{array}{l}\mathbf{0 . 1 8 2 2}^{* * * *} \\
(0.0489)\end{array}$ & & $\begin{array}{l}\mathbf{0 . 1 8 5 6} \\
(0.0505)\end{array}$ & \\
\hline Permanent contract $*$ Age & $\begin{array}{l}-0.0218^{* * * *} \\
(0.0046)\end{array}$ & $-0.0047^{* *}$ & $\begin{array}{l}-0.0218^{* * * *} \\
(0.0047)\end{array}$ & $-0.0046^{* *}$ \\
\hline Temporary contract $*$ Age & $\begin{array}{l}-0.0265^{* * *} \\
(0.0051)\end{array}$ & $(0.0021)$ & $\begin{array}{l}-0.0264^{* * * *} \\
(0.0051)\end{array}$ & $(0.0020)$ \\
\hline Permanent contract $*$ Age $^{2}$ & $\begin{array}{l}0.0002^{* * * *} \\
(0.0001)\end{array}$ & & $\begin{array}{l}0.0002^{* * *} \\
(0.0001)\end{array}$ & \\
\hline Temporary contract $*$ Age $^{2}$ & $\begin{array}{l}-0.0000 \\
(0.0002)\end{array}$ & & $\begin{array}{l}-0.0000 \\
(0.0002)\end{array}$ & \\
\hline Permanent contract * Years of education & $0.0157^{* * * *}$ & & $0.0157^{* * * *}$ & \\
\hline Temporary contract $*$ Years of education & $\begin{array}{l}(0.0032) \\
0.0153^{* *} \\
(0.0077)\end{array}$ & $\begin{array}{l}-0.0004 \\
(0.0068)\end{array}$ & $\begin{array}{l}(0.0032) \\
0.0154^{* *} \\
(0.0077)\end{array}$ & $\begin{array}{l}-0.0003 \\
(0.0068)\end{array}$ \\
\hline Permanent contract * Overeducated & $\begin{array}{l}-0.1102^{* * * *} \\
(0.0190)\end{array}$ & 0.0495 & $\begin{array}{l}-0.1102^{* * * *} \\
(0.0190)\end{array}$ & 0.0495 \\
\hline Temporary contract * Overeducated & $\begin{array}{l}-0.0606^{* * *} \\
(0.0230)\end{array}$ & $(0.0369)$ & $\begin{array}{c}-0.0606^{* * * *} \\
(0.0230)\end{array}$ & $(0.0369)$ \\
\hline Permanent contract * Undereducated & $\begin{array}{l}0.1409^{* * * *} \\
(0.0296)\end{array}$ & 0.1218 & $\begin{array}{l}0.1410^{* * *} \\
(0.0296)\end{array}$ & 0.1242 \\
\hline Temporary contract * Undereducated & $\begin{array}{l}0.2627^{* * *} \\
(0.0864)\end{array}$ & $(0.0937)$ & $\begin{array}{l}0.2652^{* * * *} \\
(0.0864)\end{array}$ & $(0.0937)$ \\
\hline Permanent contract $*$ Tenure & $\begin{array}{l}-0.0024^{* * *} \\
(0.0010)\end{array}$ & $-0.0059^{* *}$ & $\begin{array}{l}-0.0023^{* *} \\
(0.0010)\end{array}$ & $-0.0058^{* *}$ \\
\hline Temporary contract $*$ Tenure & $\begin{array}{l}-0.0082^{* * * *} \\
(0.0031)\end{array}$ & $(0.0029)$ & $\begin{array}{c}-0.0082^{* * * *} \\
(0.0031)\end{array}$ & $(0.0028)$ \\
\hline Permanent contract $*$ Working hours & $\begin{array}{l}0.0078^{* * *} \\
(0.0011)\end{array}$ & & $\begin{array}{l}0.0078^{* * *} \\
(0.0011)\end{array}$ & \\
\hline Temporary contract * Working hours & $\begin{array}{c}0.0016 \\
(0.0022)\end{array}$ & & $\begin{array}{l}0.0016 \\
(0.0022)\end{array}$ & \\
\hline Permanent contract * Elaborate learning & $\begin{array}{l}0.2049^{* * *} \\
(0.0132)\end{array}$ & -0.0048 & $\begin{array}{l}0.2088^{* * *} \\
(0.0132)\end{array}$ & -0.0087 \\
\hline Temporary contract * Elaborate learning & $\begin{array}{l}0.2001^{* * * *} \\
(0.0345)\end{array}$ & $(0.0283)$ & $\begin{array}{l}0.2001^{* * * *} \\
(0.0345)\end{array}$ & $(0.0290)$ \\
\hline Temporary contract & $\begin{array}{l}0.5957^{* * *} \\
(0.2746)\end{array}$ & & $\begin{array}{l}0.5993^{* *} \\
(0.2785)\end{array}$ & \\
\hline _cons & $\begin{array}{l}-0.3196^{* * *} \\
(0.1098)\end{array}$ & & $\begin{array}{l}-0.3220^{* * * *} \\
(0.1105)\end{array}$ & \\
\hline Treatment interactions with: & & & & \\
\hline $\begin{array}{l}\text { Other controls } \\
\text { Country dummies }\end{array}$ & $\begin{array}{l}\text { yes } \\
\text { yes }\end{array}$ & & $\begin{array}{l}\text { yes } \\
\text { yes }\end{array}$ & \\
\hline Temporary Contract Equation & $A M E$ & & $A M E$ & \\
\hline Unemployment & $\begin{array}{l}0.0145^{* *} \\
(0.0059)\end{array}$ & & $\begin{array}{l}0.0226^{* * *} \\
(0.0080)\end{array}$ & \\
\hline Unemployment *EPL moderate & & & $\begin{array}{l}-0.0122^{*} \\
(0.0072)\end{array}$ & \\
\hline Unemployment * EPL low & & & $\begin{array}{l}-0.0525^{* * * *} \\
(0.0061)\end{array}$ & \\
\hline Other controls & yes & & yes & \\
\hline Country dummies & yes & & yes & \\
\hline athrho & $\begin{array}{c}-0.0509^{* * *} \\
(0.0171)\end{array}$ & & $\begin{array}{c}-0.0532^{* * *} \\
(0.0178)\end{array}$ & \\
\hline Insigma & $\begin{array}{c}-0.1072^{* * * *} \\
(0.0358)\end{array}$ & & $\begin{array}{c}-0.1072^{* * * *} \\
(0.0359)\end{array}$ & \\
\hline Wald test of indep. Eqns $(r h o=0)$ & $\begin{array}{c}\text { Chi2 }(1)=8.85 \\
(p=0.0029)\end{array}$ & & $\begin{array}{c}\text { Chi2(1) = 8.90 } \\
(p=0.0028)\end{array}$ & \\
\hline$N$ & 25,366 & & 25,366 & \\
\hline
\end{tabular}

The informal learning dependant variable is standardised. The standardised unemployment rate is used as instrument in column (1), and column (2) adds as instruments the interactions of the standardised unemployment rate with 2 of the 3 dummies of EPL for permanent employment. AME correspond to average marginal effects. All regressions include the same control variables as reported in Table 3. Standard errors clustered at country level are shown in parenthesis. ${ }^{*} p<0.10,{ }^{* *} p<0.05,{ }^{* * *} p<0.01$. 
Figure 1. Estimated difference in informal learning between temporary and permanent employees over age

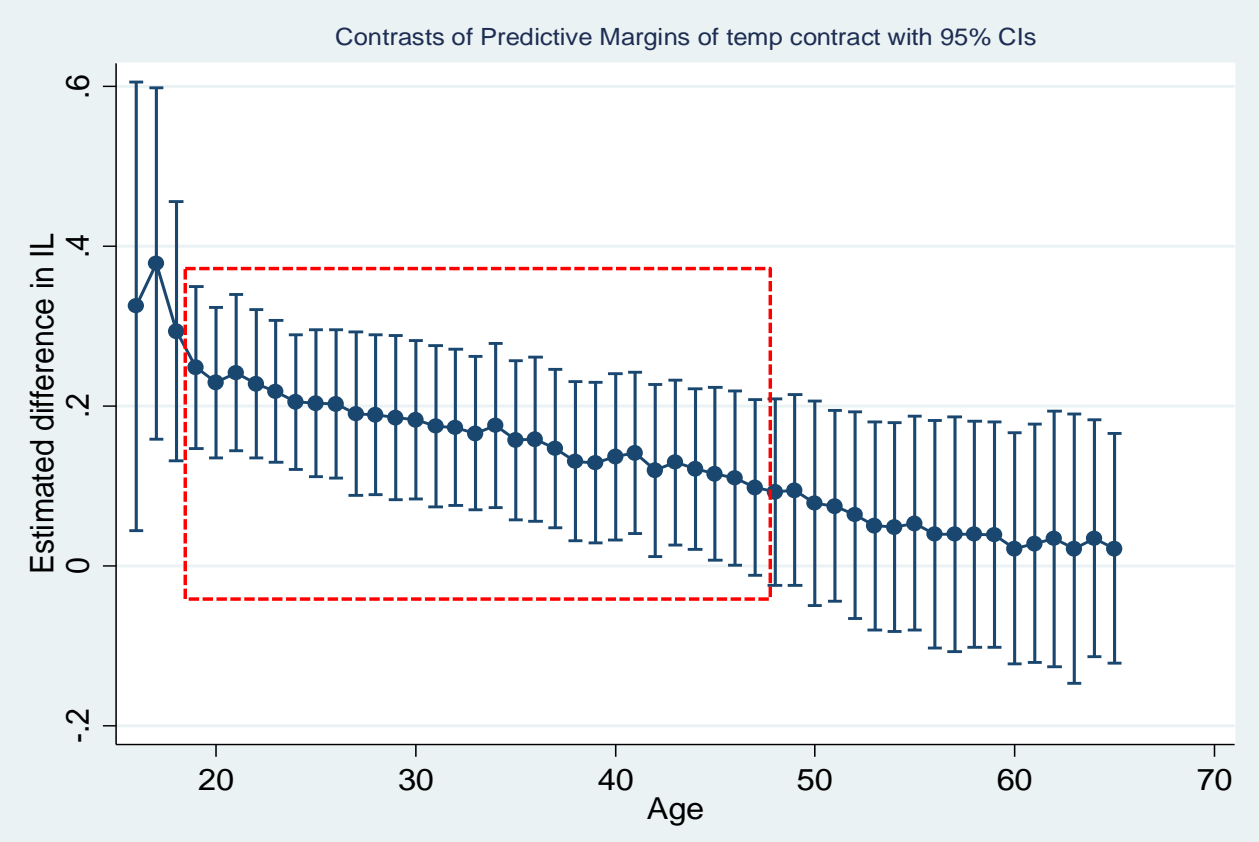

Marginal effects computed based on the full endogenous switching regression model (2) in Table 4. The dotted line shows the marginal effects that are significant at minimum 95 percent of confidence.

Figure 2. Estimated difference in informal learning between temporary and permanent employees over years of tenure

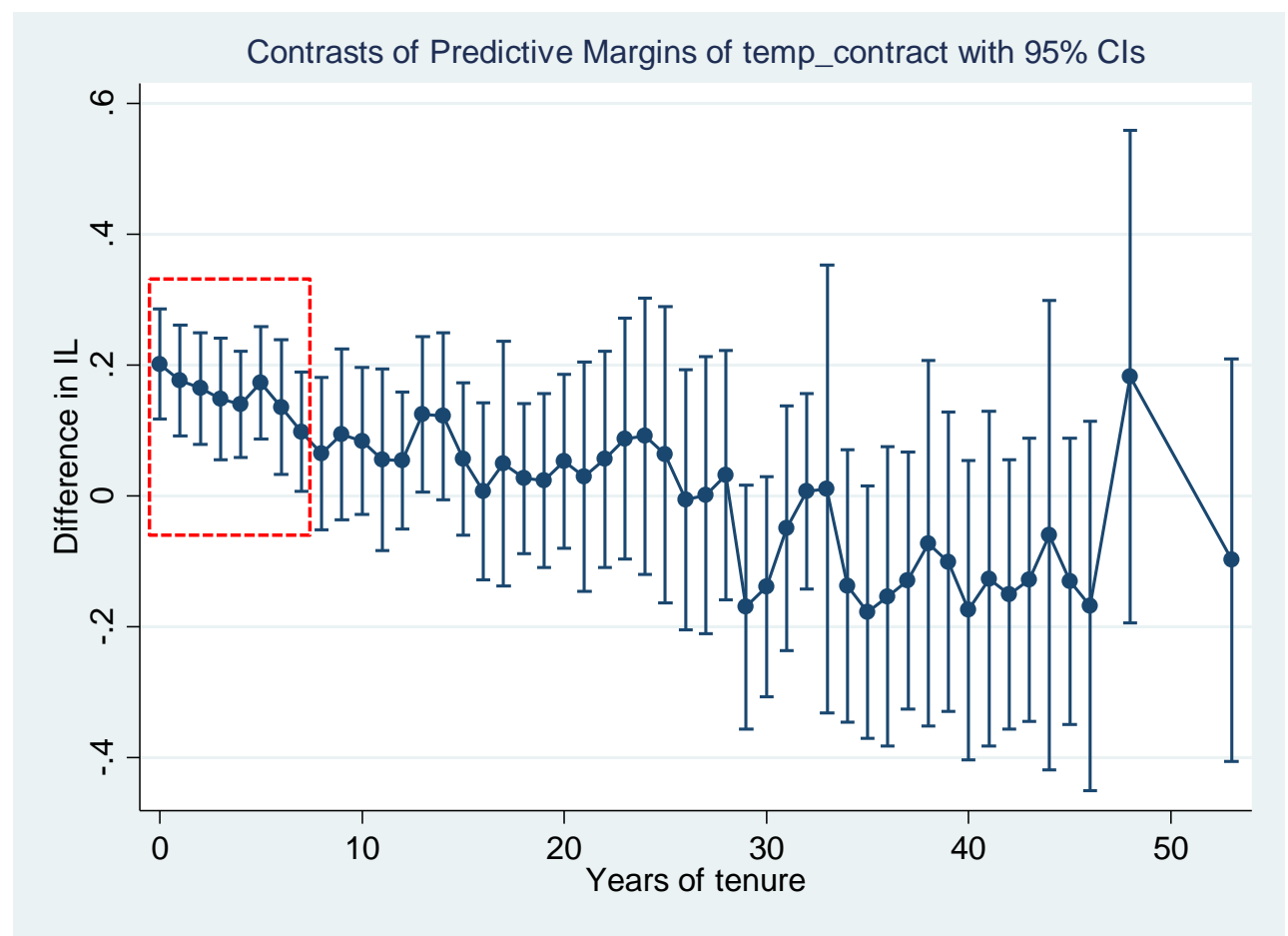

Marginal effects computed based on the full endogenous switching regression model (2) in Table 4. The dotted line shows the marginal effects that are significant at minimum 95 percent of confidence. 
Table 5. Heterogeneous effects of temporary contracts by various job content characteristics

\begin{tabular}{|c|c|c|}
\hline & $\begin{array}{c}(1) \\
\text { CF-ML } \\
\text { (1 instrument) }\end{array}$ & $\begin{array}{c}(2) \\
\text { CF-ML } \\
\text { (3 instruments) }\end{array}$ \\
\hline ATE Temporary Contract & $\begin{array}{l}0.1455^{* * *} \\
(0.0514)\end{array}$ & $\begin{array}{l}0.1497^{* * *} \\
(0.0507)\end{array}$ \\
\hline Permanent contract * High skilled occupations & $\begin{array}{l}0.2194^{* * * *} \\
(0.0181)\end{array}$ & $\begin{array}{l}0.2195^{* * *} \\
(0.0180)\end{array}$ \\
\hline Temporary contract * High skilled occupations & $\begin{array}{l}0.1920^{* * * *} \\
(0.0465)\end{array}$ & $\begin{array}{l}0.1926^{* * *} \\
(0.0464)\end{array}$ \\
\hline Difference & $\begin{array}{l}-0.0274 \\
(0.0441)\end{array}$ & $\begin{array}{l}-0.0269 \\
(0.0441)\end{array}$ \\
\hline athrho & $\begin{array}{l}-0.0357^{* *} \\
(0.0214)\end{array}$ & $\begin{array}{l}-0.0383^{* *} \\
(0.0206)\end{array}$ \\
\hline Wald test of indep. Eqns. $(r h o=0)$ & $\begin{array}{c}\text { Chi2 }(1)=3.93 \\
(p=0.0474)\end{array}$ & $\begin{array}{c}\text { Chi2(1) }=4.04 \\
(p=0.0444)\end{array}$ \\
\hline$N$ & 25,366 & 25,366 \\
\hline ATE Temporary Contract & $\begin{array}{l}0.1656^{* * *} \\
(0.0511)\end{array}$ & $\begin{array}{l}0.1695^{* * *} \\
(0.0508)\end{array}$ \\
\hline Permanent contract * Task discretion & $\begin{array}{l}0.0794^{* * * *} \\
(0.0134)\end{array}$ & $\begin{array}{l}0.0794^{* * *} \\
(0.0134)\end{array}$ \\
\hline Temporary contract $*$ Task discretion & $\begin{array}{l}0.0809^{* * * *} \\
(0.0272)\end{array}$ & $\begin{array}{l}0.0812^{* * * *} \\
(0.0272)\end{array}$ \\
\hline Difference & $\begin{array}{c}0.0014 \\
(0.0299)\end{array}$ & $\begin{array}{c}0.0018 \\
(0.0298)\end{array}$ \\
\hline athrho & $\begin{array}{c}-0.0404^{* * *} \\
(0.0200)\end{array}$ & $\begin{array}{c}-0.0428^{* * *} \\
(0.0192)\end{array}$ \\
\hline Wald test of indep. Eqns. $(r h o=0)$ & $\begin{array}{c}\text { Chi2(1) }=4.09 \\
(p=0.0430)\end{array}$ & $\begin{array}{c}\text { Chi2(1) }=4.97 \\
(p=0.0258)\end{array}$ \\
\hline$N$ & 25,365 & 25,365 \\
\hline ATE Temporary Contract & $\begin{array}{l}0.1643^{* * *} \\
(0.0552)\end{array}$ & $\begin{array}{l}0.1680 \\
(0.0547)\end{array}$ \\
\hline Permanent contract * Complex problems & $\begin{array}{l}0.3549^{* * * *} \\
(0.0164)\end{array}$ & $\begin{array}{l}0.3549^{* * *} \\
(0.0164)\end{array}$ \\
\hline Temporary contract $*$ Complex problems & $\begin{array}{l}0.3950^{* * * *} \\
(0.0574)\end{array}$ & $\begin{array}{l}0.3950^{* * * *} \\
(0.0573)\end{array}$ \\
\hline Difference & $\begin{array}{c}0.0402 \\
(0.0541)\end{array}$ & $\begin{array}{c}0.0401 \\
(0.0541)\end{array}$ \\
\hline athrho & $\begin{array}{l}-0.0407^{*} \\
(0.0210)\end{array}$ & $\begin{array}{l}-0.0431^{* * *} \\
(0.0202)\end{array}$ \\
\hline Wald test of indep. Eqns. $(r h o=0)$ & $\begin{array}{c}\text { Chi2(1) = } 3.96 \\
(p=0.0466)\end{array}$ & $\begin{array}{c}\text { Chi2(1) }=4.56 \\
(p=0.0327)\end{array}$ \\
\hline$N$ & 25,334 & 25,334 \\
\hline ATE Temporary Contract & $\begin{array}{l}0.1761 \\
(0.0577)\end{array}$ & $\begin{array}{l}0.1800^{* * *} \\
(0.0576)\end{array}$ \\
\hline Permanent contract * Simple problems & $\begin{array}{l}0.3138^{* * *} \\
(0.0177)\end{array}$ & $\begin{array}{l}0.3138^{* * * *} \\
(0.0176)\end{array}$ \\
\hline Temporary contract $*$ Simple problems & $\begin{array}{l}0.3190^{* * *} \\
(0.0477)\end{array}$ & $\begin{array}{l}0.3191^{* * * *} \\
(0.0477)\end{array}$ \\
\hline Difference & $\begin{array}{c}0.0051 \\
(0.0476)\end{array}$ & $\begin{array}{c}0.0053 \\
(0.0476)\end{array}$ \\
\hline athrho & $\begin{array}{c}-0.0457^{* *} \\
(0.0223)\end{array}$ & $\begin{array}{c}-0.0481^{* * *} \\
(0.0216)\end{array}$ \\
\hline Wald test of indep. Eqns. $(r h o=0)$ & $\begin{array}{c}\text { Chi2 }(1)=4.18 \\
(p=0.0409)\end{array}$ & $\begin{array}{c}\text { Chi2(1) }=4.96 \\
(p=0.0259)\end{array}$ \\
\hline$N$ & 25,343 & 25,343 \\
\hline ATE Temporary Contract & $\begin{array}{l}\mathbf{0 . 1 5 3 1} 1^{* * * 4} \\
(\mathbf{0 . 0 4 8 7 )}\end{array}$ & $\begin{array}{l}0.1565^{* * *} \\
(0.0490)\end{array}$ \\
\hline Permanent contract * Team work & $\begin{array}{l}0.2284^{* * * *} \\
(0.0228)\end{array}$ & $\begin{array}{l}0.2284^{* * *} \\
(0.0229)\end{array}$ \\
\hline Temporary contract $*$ Team work & $\begin{array}{l}0.2694^{* * * *} \\
(0.0349)\end{array}$ & $\begin{array}{l}0.2693^{* * * *} \\
(0.0350)\end{array}$ \\
\hline Difference & $\begin{array}{c}0.0409 \\
(0.0359)\end{array}$ & $\begin{array}{c}0.0408 \\
(0.0360)\end{array}$ \\
\hline athrho & $\begin{array}{c}-0.0388^{* *} \\
(0.0196)\end{array}$ & $\begin{array}{l}-0.0410^{* *} \\
(0.0193)\end{array}$ \\
\hline Wald test of indep. Eqns. $(r h o=0)$ & $\begin{array}{c}\text { Chi2 }(1)=3.92 \\
(p=0.0478)\end{array}$ & $\begin{array}{c}\text { Chi2 }(1)=4.52 \\
(p=0.0336)\end{array}$ \\
\hline$N$ & 25,349 & 25,349 \\
\hline
\end{tabular}




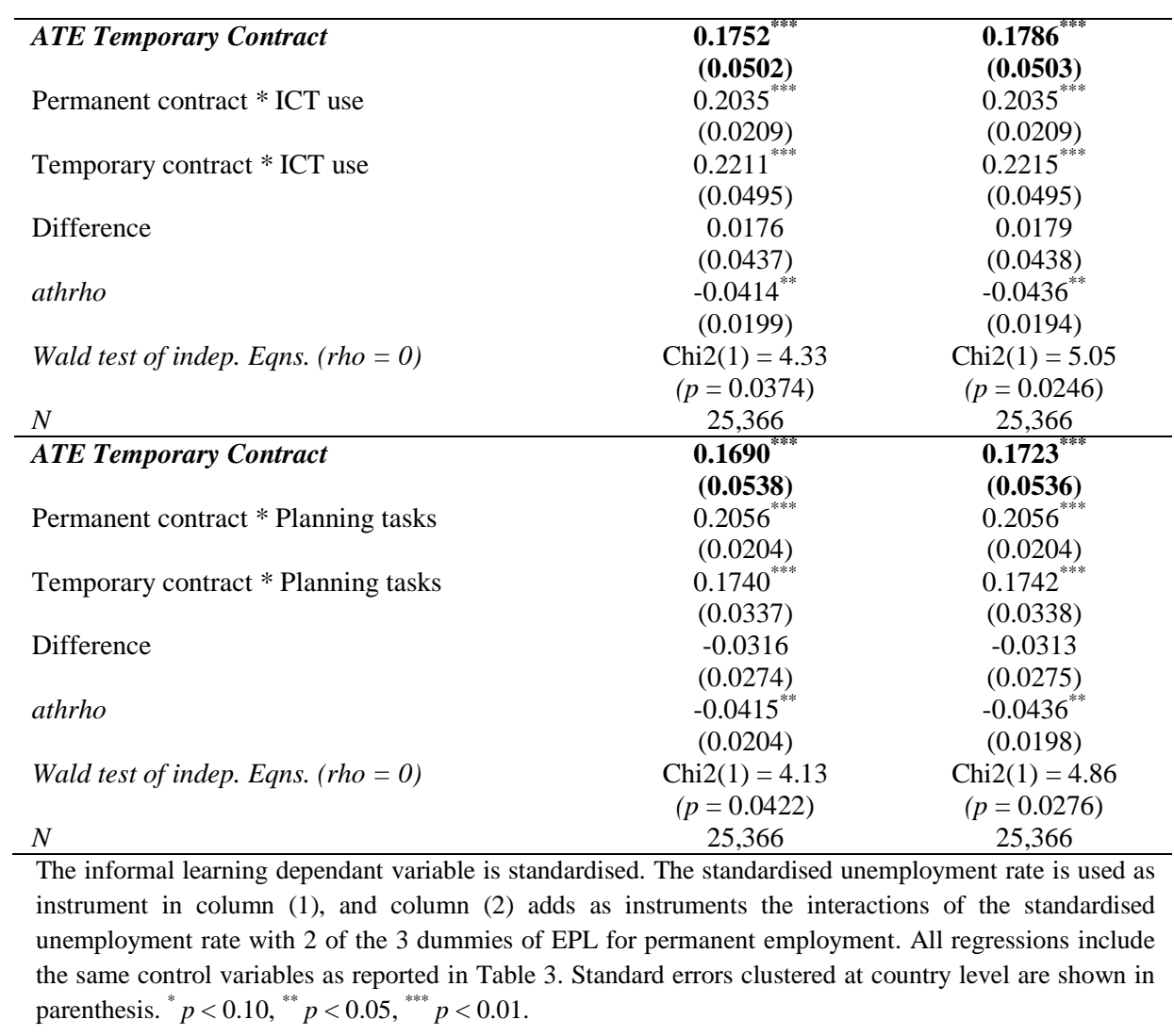


Table 6. Estimations of job-related training participation

\begin{tabular}{|c|c|c|c|c|}
\hline & $\begin{array}{l}\text { (1) } \\
\text { OLS }\end{array}$ & $\begin{array}{c}(2) \\
\text { Probit }\end{array}$ & $\begin{array}{c}\text { (3) } \\
\mathrm{CF}-\mathrm{ML} \\
\text { (1 instrument) }\end{array}$ & $\begin{array}{c}\text { (4) } \\
\mathrm{CF}-\mathrm{ML} \\
\text { (3 instruments) }\end{array}$ \\
\hline Training Equation & & $A M E$ & $A M E$ & AME \\
\hline Temporary contract & $\begin{array}{l}-0.0619^{* * *} \\
(0.0124)\end{array}$ & $\begin{array}{l}-0.0648^{* * *} \\
(0.0133)\end{array}$ & $\begin{array}{l}-0.0751^{* * *} \\
(0.0131)\end{array}$ & $\begin{array}{l}-0.0763^{* * *} \\
(0.0134)\end{array}$ \\
\hline Age & $\begin{array}{l}0.0116^{* * * *} \\
(0.0022)\end{array}$ & $\begin{array}{l}0.0114^{* * *} \\
(0.0021)\end{array}$ & $\begin{array}{l}0.0161^{* * * *} \\
(0.0038)\end{array}$ & $\begin{array}{l}0.0158^{* * *} \\
(0.0029)\end{array}$ \\
\hline $\mathrm{Age}^{2}$ & $\begin{array}{l}-0.0002^{* * *} \\
(0.0000)\end{array}$ & $\begin{array}{l}-0.0002^{* * *} \\
(0.0000)\end{array}$ & $\begin{array}{l}-0.0002^{* * * *} \\
(0.0000)\end{array}$ & $\begin{array}{l}-0.0002^{* * * *} \\
(0.0000)\end{array}$ \\
\hline Years of education & $\begin{array}{l}0.0161^{* * *} \\
(0.0016)\end{array}$ & $\begin{array}{l}0.0163^{* * *} \\
(0.0016)\end{array}$ & $\begin{array}{l}0.0165^{* * *} \\
(0.0016)\end{array}$ & $\begin{array}{l}0.0173^{* * *} \\
(0.0017)\end{array}$ \\
\hline Overeducated & $\begin{array}{l}-0.0168^{* *} \\
(0.0078)\end{array}$ & $\begin{array}{l}-0.0167^{* *} \\
(0.0077)\end{array}$ & $\begin{array}{l}-0.0180^{* *} \\
(0.0079)\end{array}$ & $\begin{array}{l}-0.0198^{* *} \\
(0.0082)\end{array}$ \\
\hline Undereducated & $\begin{array}{l}0.0293^{* *} \\
(0.0110)\end{array}$ & $\begin{array}{l}0.0280^{* * *} \\
(0.0102)\end{array}$ & $\begin{array}{l}0.0278^{* * *} \\
(0.0102)\end{array}$ & $\begin{array}{l}0.0284^{* * *} \\
(0.0104)\end{array}$ \\
\hline Working hours & $\begin{array}{l}0.0031^{* * * *} \\
(0.0005)\end{array}$ & $\begin{array}{l}0.0030^{* * * *} \\
(0.0005)\end{array}$ & $\begin{array}{l}0.0030^{* * * *} \\
(0.0005)\end{array}$ & $\begin{array}{l}0.0029^{* * *} \\
(0.0005)\end{array}$ \\
\hline Tenure & $\begin{array}{c}0.0020^{* * *} \\
(0.000335)\end{array}$ & $\begin{array}{c}0.0020^{* * *} \\
(0.000326)\end{array}$ & $\begin{array}{c}0.0029^{* * *} \\
(0.000338)\end{array}$ & $\begin{array}{c}0.0024^{* * *} \\
(0.000407)\end{array}$ \\
\hline Elaborate learning & $\begin{array}{l}0.0356^{* * *} \\
(0.0039)\end{array}$ & $\begin{array}{l}0.0378^{* * *} \\
(0.0045)\end{array}$ & $\begin{array}{l}0.0377^{* * *} \\
(0.0041)\end{array}$ & $\begin{array}{l}0.0382^{* * *} \\
(0.0042)\end{array}$ \\
\hline _cons & $\begin{array}{l}-0.3756^{* * *} \\
(0.0684)\end{array}$ & & & \\
\hline Industry \& firm size dummies & yes & yes & yes & yes \\
\hline Country dummies & yes & yes & yes & yes \\
\hline Temporary Contract Equation & & & $A M E$ & AME \\
\hline Unemployment & & & $\begin{array}{l}0.0131^{* *} \\
(0.0061)\end{array}$ & $\begin{array}{l}0.0186^{* *} \\
(0.0087)\end{array}$ \\
\hline Unemployment * EPL moderate & & & & $\begin{array}{l}-0.0107 \\
(0.0082)\end{array}$ \\
\hline Unemployment * EPL low & & & & $\begin{array}{l}-0.0613^{* * *} \\
(0.0073)\end{array}$ \\
\hline Age & & & $\begin{array}{l}-0.0218^{* * *} \\
(0.0029)\end{array}$ & $\begin{array}{l}-0.0223^{* * * *} \\
(0.0019)\end{array}$ \\
\hline $\mathrm{Age}^{2}$ & & & $\begin{array}{l}0.0002^{* * * *} \\
(0.0000)\end{array}$ & $\begin{array}{l}0.0002^{* * *} \\
(0.0000)\end{array}$ \\
\hline Years of education & & & $\begin{array}{l}-0.0025 \\
(0.0017)\end{array}$ & $\begin{array}{l}-0.0006 \\
(0.0017)\end{array}$ \\
\hline Elaborate learning & & & $\begin{array}{c}0.0020 \\
(0.0131)\end{array}$ & $\begin{array}{c}0.0015 \\
(0.0019)\end{array}$ \\
\hline $\begin{array}{l}\text { Other controls } \\
\text { Country dummies }\end{array}$ & & & $\begin{array}{l}\text { yes } \\
\text { yes }\end{array}$ & $\begin{array}{l}\text { yes } \\
\text { yes }\end{array}$ \\
\hline First-stage Tests & & & $\begin{array}{l}\text { Wald chi2(45) } \\
=2071.1\end{array}$ & $\begin{array}{l}\text { Wald chi2(47) } \\
=2102.6\end{array}$ \\
\hline $\begin{array}{l}\text { Adj. R2 First-stage } \\
\text { athrho }\end{array}$ & & & $\begin{array}{c}0.1230 \\
-1.2761^{* * *} \\
(0.0872)\end{array}$ & $\begin{array}{c}0.1262 \\
-1.2880^{* * *} \\
(0.3194)\end{array}$ \\
\hline Insigma & & & $\begin{array}{l}-8.6042 \\
(5.5440)\end{array}$ & $\begin{array}{l}-8.3152^{* *} \\
(0.9946)\end{array}$ \\
\hline Wald test of indep. eqns. $(r h o=0)$ & & & $\begin{array}{c}\text { Chi2(1) }=3.17 \\
(p=0.0750)\end{array}$ & $\begin{array}{c}\text { Chi2(1) = 3.51 } \\
(p=0.0609)\end{array}$ \\
\hline$N$ & 22,447 & 22,447 & 22,447 & 22,447 \\
\hline$R^{2}$ & 0.1895 & 0.1489 & . & . \\
\hline
\end{tabular}


Figure 3. Informal learning and training Temporary workers

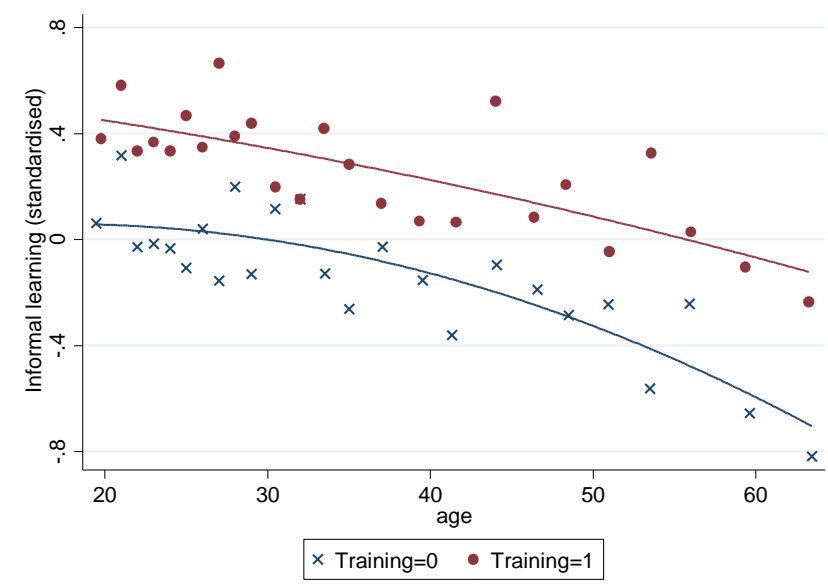

Figure 4. Informal learning and training Permanent workers

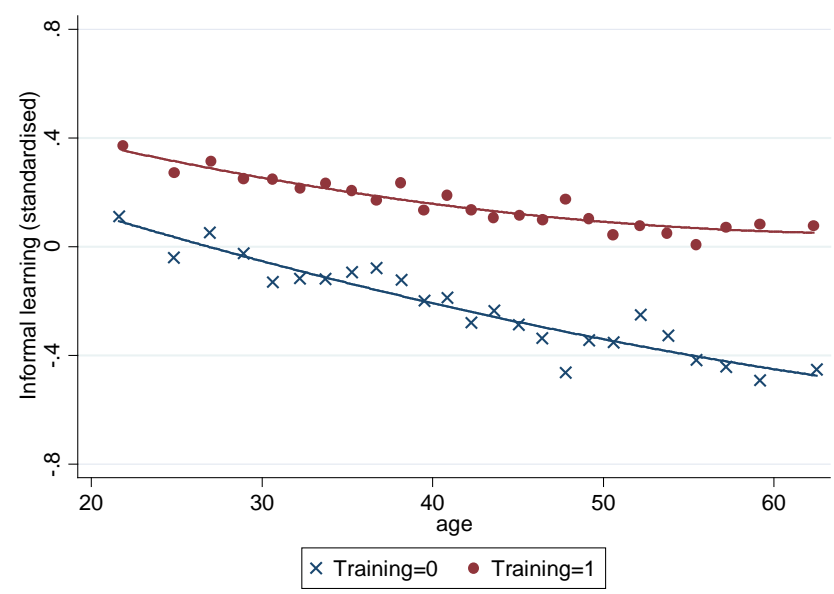


Table 7. Estimations on complementarity between informal learning and training participation

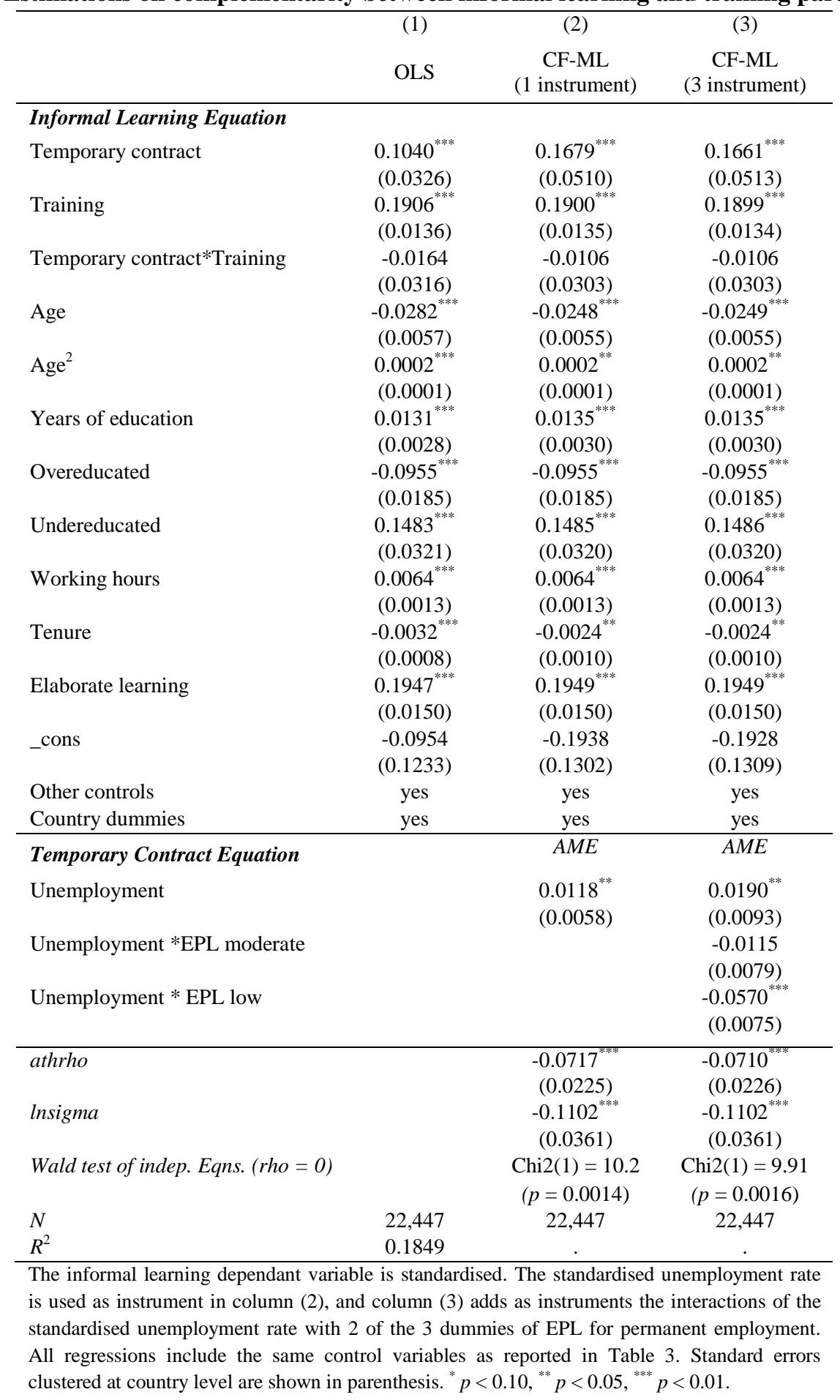




\section{APPENDIX}

Figure A1. Correlation graph between temporary contracts and unemployment rate

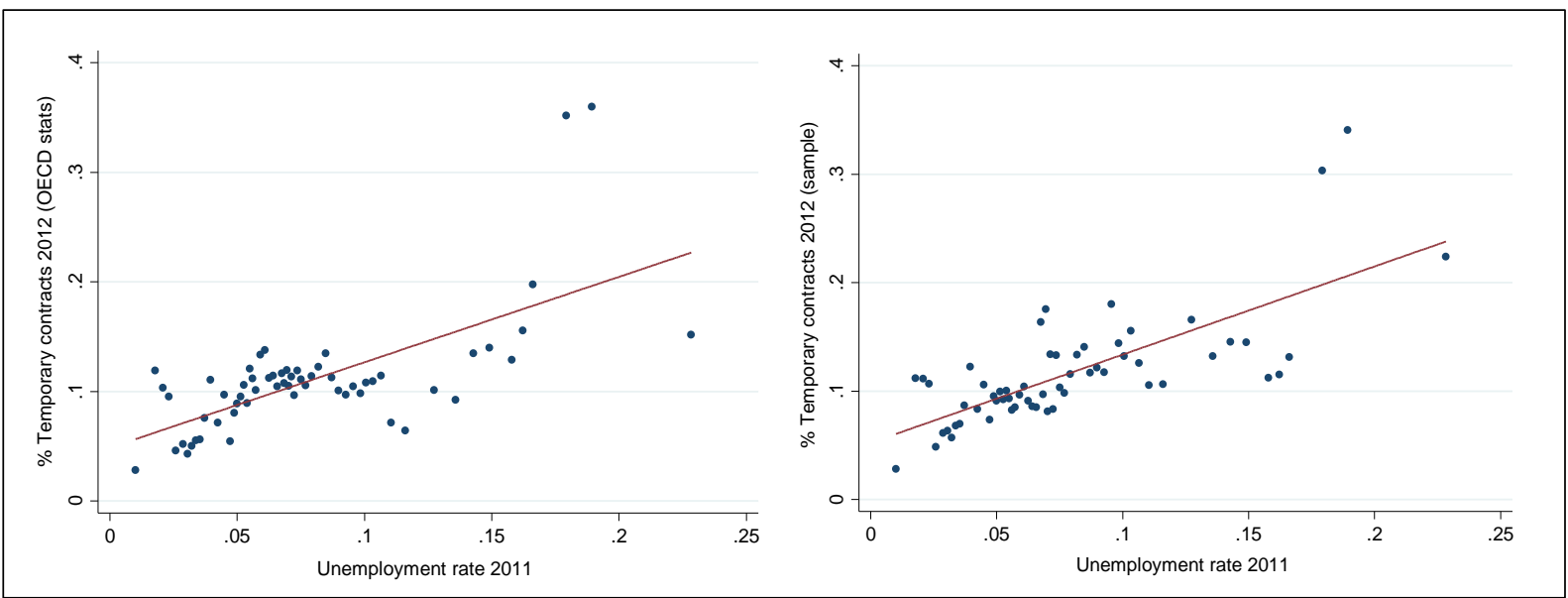

These figures show the correlation between the unemployment rate in 2011 and the share of temporary contracts in 2012, both variables collapsed by correspondent country and age group. Each point in the graphs is a bin for 3 observations. The figure on the left side uses the OECD statistics for the percentage of temporary contracts and the figure on the rigth side is based on our sample data. 
Table A1. CF-ML estimations of on-the-job informal learning intensity with one instrument

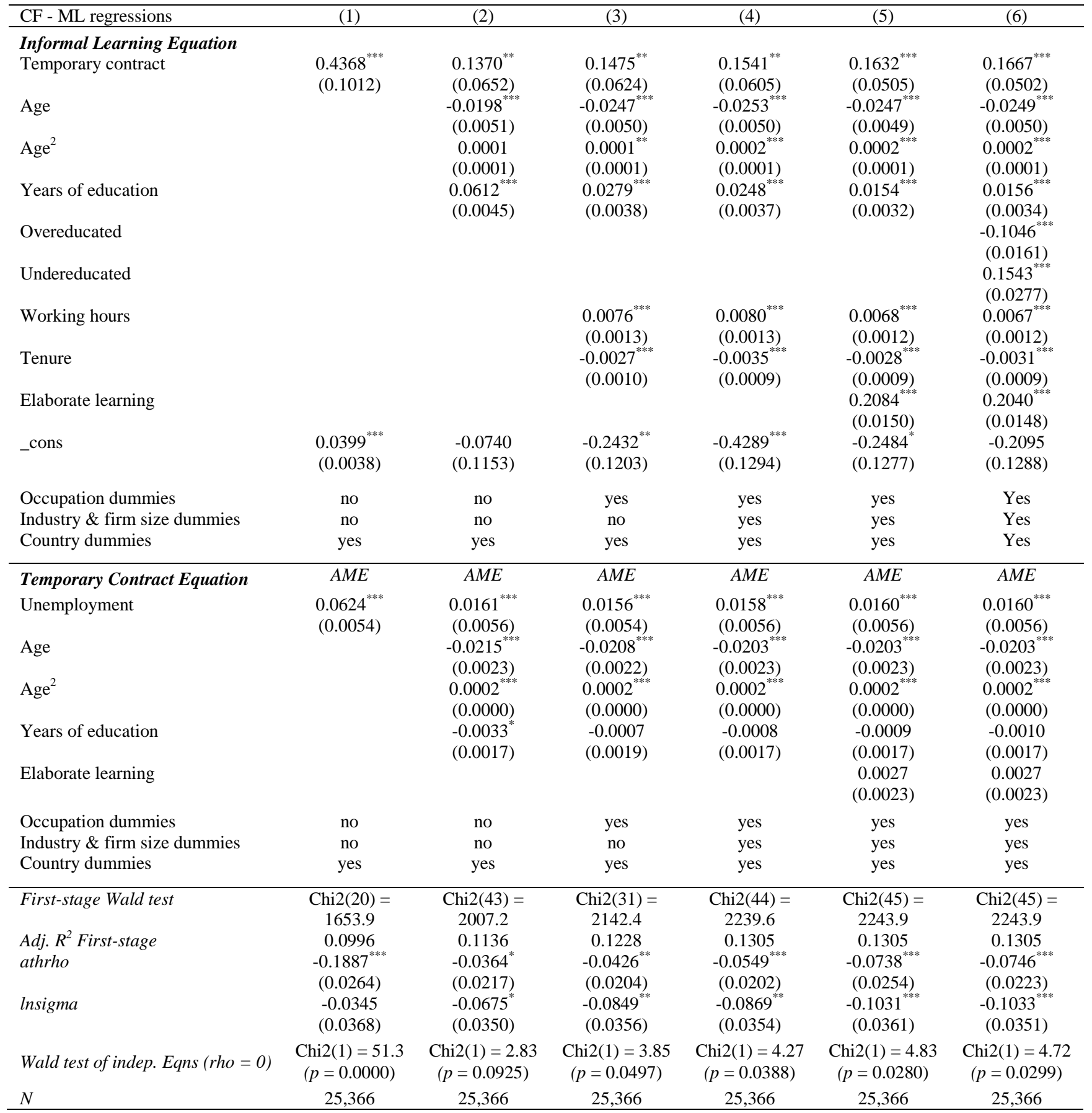

The informal learning dependant variable is standardised. The standardised unemployment rate is used as instrument in all specifications. AME correspond to average marginal effects. Specification (6) is our preferred specification reported as specification (4) in Table 3. Standard errors clustered at country level are shown in parenthesis. ${ }^{*} p<0.10,{ }^{* *} p<0.05,{ }^{* * *} p<0.01$. 
Table A2. CF-ML estimations of on-the-job informal learning intensity with three instruments

\begin{tabular}{|c|c|c|c|c|c|c|}
\hline CF - ML regressions & $(1)$ & $(2)$ & (3) & $(4)$ & $(5)$ & (6) \\
\hline \multicolumn{7}{|l|}{ Informal Learning Equation } \\
\hline Temporary contract & $\begin{array}{l}0.4356^{* * *} \\
(0.0619)\end{array}$ & $\begin{array}{l}0.1381^{* *} \\
(0.0653)\end{array}$ & $\begin{array}{l}0.1484^{* *} \\
(0.0623)\end{array}$ & $\begin{array}{l}0.1548^{* *} \\
(0.0602)\end{array}$ & $\begin{array}{l}0.16499^{* * *} \\
(0.0503)\end{array}$ & $\begin{array}{l}0.1698^{* * *} \\
(0.0501)\end{array}$ \\
\hline Age & & $\begin{array}{l}-0.0198^{* * * *} \\
(0.0051)\end{array}$ & $\begin{array}{c}-0.0247^{* * * *} \\
(0.0051)\end{array}$ & $\begin{array}{l}-0.0253^{* * * *} \\
(0.0050)\end{array}$ & $\begin{array}{c}-0.0246^{* * *} \\
(0.0049)\end{array}$ & $\begin{array}{c}-0.0248^{* * *} \\
(0.0050)\end{array}$ \\
\hline $\operatorname{Age}^{2}$ & & $\begin{array}{c}0.0001 \\
(0.0001)\end{array}$ & $\begin{array}{l}0.0001^{* *} \\
(0.0001)\end{array}$ & $\begin{array}{l}0.0002^{* * * *} \\
(0.0001)\end{array}$ & $\begin{array}{l}0.0002^{* * * *} \\
(0.0001)\end{array}$ & $\begin{array}{l}0.0002^{* * *} \\
(0.0001)\end{array}$ \\
\hline Overeducated & & & & & & $\begin{array}{c}-0.1046^{* * * *} \\
(0.0161)\end{array}$ \\
\hline Undereducated & & & & & & $\begin{array}{l}0.1543^{* * * *} \\
(0.0277)\end{array}$ \\
\hline Working hours & & & $\begin{array}{l}0.0076^{* * *} \\
(0.0013)\end{array}$ & $\begin{array}{l}0.0080^{* * *} \\
(0.0013)\end{array}$ & $\begin{array}{l}0.0068^{* * *} \\
(0.0012)\end{array}$ & $\begin{array}{l}0.0067^{* * * *} \\
(0.0012)\end{array}$ \\
\hline Tenure & & & $\begin{array}{c}-0.0027^{* * * *} \\
(0.0010)\end{array}$ & $\begin{array}{c}-0.0035^{* * * *} \\
(0.0009)\end{array}$ & $\begin{array}{c}-0.0028^{* * *} \\
(0.0009)\end{array}$ & $\begin{array}{c}-0.0031^{* * * *} \\
(0.0009)\end{array}$ \\
\hline Elaborate learning & & & & & $\begin{array}{l}0.2084^{* * *} \\
(0.0150)\end{array}$ & $\begin{array}{l}0.2040^{* * * *} \\
(0.0148)\end{array}$ \\
\hline _cons & $\begin{array}{l}0.0400^{* * *} \\
(0.0039)\end{array}$ & $\begin{array}{l}-0.0748 \\
(0.1166)\end{array}$ & $\begin{array}{l}-0.2439^{* *} \\
(0.1216)\end{array}$ & $\begin{array}{c}-0.4294^{* * *} \\
(0.1302)\end{array}$ & $\begin{array}{l}-0.2505^{*} \\
(0.1282)\end{array}$ & $\begin{array}{c}-0.2126 \\
(0.1293)\end{array}$ \\
\hline Occupation dummies & no & no & yes & yes & yes & yes \\
\hline Industry \& firm size dummies & no & no & no & yes & yes & yes \\
\hline Country dummies & yes & yes & yes & yes & yes & yes \\
\hline Temporary Contract Equation & $A M E$ & $A M E$ & $A M E$ & $A M E$ & $A M E$ & $A M E$ \\
\hline Unemployment & $\begin{array}{l}0.0712^{* * *} \\
(0.0107)\end{array}$ & $\begin{array}{l}0.0245^{* * *} \\
(0.0072)\end{array}$ & $\begin{array}{l}0.0236^{* * *} \\
(0.0070)\end{array}$ & $\begin{array}{l}0.0236^{* * *} \\
(0.0073)\end{array}$ & $\begin{array}{l}0.0238^{* * *} \\
(0.0073)\end{array}$ & $\begin{array}{l}0.0239^{* * *} \\
(0.0073)\end{array}$ \\
\hline Unemployment *EPL moderate & $\begin{array}{l}-0.0119 \\
(0.0129)\end{array}$ & $\begin{array}{l}-0.0127 \\
(0.0084)\end{array}$ & $\begin{array}{l}-0.0121 \\
(0.0080)\end{array}$ & $\begin{array}{l}-0.0116 \\
(0.0078)\end{array}$ & $\begin{array}{l}-0.0116 \\
(0.0078)\end{array}$ & $\begin{array}{l}-0.0117 \\
(0.0078)\end{array}$ \\
\hline Unemployment * EPL low & $\begin{array}{l}-0.0387^{* *} \\
(0.0157)\end{array}$ & $\begin{array}{c}-0.0614^{* * * *} \\
(0.0072)\end{array}$ & $\begin{array}{c}-0.0612^{* * * *} \\
(0.0064)\end{array}$ & $\begin{array}{c}-0.0623^{* * * *} \\
(0.0064)\end{array}$ & $\begin{array}{c}-0.0625^{* * * *} \\
(0.0064)\end{array}$ & $\begin{array}{c}-0.0625^{* * * *} \\
(0.0064)\end{array}$ \\
\hline $\operatorname{Age}^{2}$ & & $\begin{array}{l}0.0002^{* * *} \\
(0.0000)\end{array}$ & $\begin{array}{l}0.0002^{* * *} \\
(0.0000)\end{array}$ & $\begin{array}{l}0.0002^{* * *} \\
(0.0000)\end{array}$ & $\begin{array}{l}0.0002^{* * *} \\
(0.0000)\end{array}$ & $\begin{array}{l}0.0002^{* * * *} \\
(0.0000)\end{array}$ \\
\hline Years of education & & $\begin{array}{l}-0.0033^{*} \\
(0.0017)\end{array}$ & $\begin{array}{l}-0.0008 \\
(0.0019)\end{array}$ & $\begin{array}{l}-0.0009 \\
(0.0017)\end{array}$ & $\begin{array}{l}-0.0010 \\
(0.0017)\end{array}$ & $\begin{array}{l}-0.0010 \\
(0.0017)\end{array}$ \\
\hline Elaborate learning & & & & & $\begin{array}{c}0.0029 \\
(0.0023)\end{array}$ & $\begin{array}{c}0.0028 \\
(0.0023)\end{array}$ \\
\hline Occupation dummies & no & no & yes & yes & yes & yes \\
\hline Industry \& firm size dummies & no & no & no & yes & yes & yes \\
\hline Country dummies & yes & yes & yes & yes & yes & yes \\
\hline First-stage Wald test & $\begin{array}{c}\text { Chi2(22) }= \\
1644.6\end{array}$ & $\begin{array}{c}\text { Chi2(25) }= \\
2012.2\end{array}$ & $\begin{array}{c}\text { Chi2(33) = } \\
2145.1\end{array}$ & $\begin{array}{c}\text { Chi2(46) }= \\
2241.6\end{array}$ & $\begin{array}{c}\text { Chi2(47) }= \\
2245.6\end{array}$ & $\begin{array}{c}\text { Chi2(47) }= \\
2245.6\end{array}$ \\
\hline $\begin{array}{l}\text { Adj. } R^{2} \text { First-stage } \\
\text { athrho }\end{array}$ & $\begin{array}{c}0.1006 \\
-0.1882^{* * *} \\
(0.0266)\end{array}$ & $\begin{array}{l}0.1155 \\
-0.0361^{*} \\
(0.0216)\end{array}$ & $\begin{array}{c}0.1247 \\
-0.0435^{\text {** }} \\
(0.0202)\end{array}$ & $\begin{array}{c}0.1324 \\
-0.0567^{* * *} \\
(0.0201)\end{array}$ & $\begin{array}{c}0.1325 \\
-0.0752^{* * *} \\
(0.0238)\end{array}$ & $\begin{array}{c}0.1325 \\
-0.0774^{* * *} \\
(0.0219)\end{array}$ \\
\hline Insigma & $\begin{array}{l}-0.0345 \\
(0.0368)\end{array}$ & $\begin{array}{l}-0.0675^{*} \\
(0.0350)\end{array}$ & $\begin{array}{l}-0.0848^{* * *} \\
(0.0356)\end{array}$ & $\begin{array}{l}-0.0869^{* *} \\
(0.0354)\end{array}$ & $\begin{array}{l}-0.1031^{* * * *} \\
(0.0361)\end{array}$ & $\begin{array}{c}-0.1055^{* * *} \\
(0.0361)\end{array}$ \\
\hline Wald test of indep. Eqns $(r h o=0)$ & $\begin{array}{c}\text { Chi2 }(1)=50.1 \\
(p=0.0000)\end{array}$ & $\begin{array}{c}\text { Chi2 }(1)=3.03 \\
(p=0.0817)\end{array}$ & $\begin{array}{c}\text { Chi2 }(1)=4.08 \\
(p=0.0434)\end{array}$ & $\begin{array}{c}\text { Chi2 }(1)=4.82 \\
(p=0.0281)\end{array}$ & $\begin{array}{c}\text { Chi2(1) }=5.53 \\
(p=0.0187)\end{array}$ & $\begin{array}{c}\text { Chi2(1) }=5.60 \\
(p=0.0179)\end{array}$ \\
\hline$N$ & 25,366 & 25,366 & 25,366 & 25,366 & 25,366 & 25,366 \\
\hline
\end{tabular}

The informal learning dependant variable is standardised. The standardised unemployment rate and its interaction with 2 of the 3 dummies of EPL for permanent employment are used as instruments in all specifications. AME correspond to average marginal effects. Specification (6) is our preferred specification reported as specification (5) in Table 3. Standard errors clustered at country level are shown in parenthesis. ${ }^{*} p<0.10,{ }^{* *} p<0.05$, ${ }^{* * *} p<$ 0.01 . 
Table A3. Estimations of informal learning intensity under alternative treatment specifications

\begin{tabular}{|c|c|c|c|c|c|c|}
\hline & $\begin{array}{c}\text { ATE } \\
\text { (1 instrument) } \\
\end{array}$ & $\rho$ & $\begin{array}{l}\text { Wald test } \\
\rho=0\end{array}$ & $\begin{array}{c}\text { ATE } \\
\text { (3 instruments) } \\
\end{array}$ & $\rho$ & $\begin{array}{l}\text { Wald test } \\
\rho=0\end{array}$ \\
\hline (1) Baseline CF-ML results in Table 3 & $\begin{array}{c}0.1667^{* * *} \\
(0.0502)\end{array}$ & $\begin{array}{l}-0.0746^{* * *} \\
(0.0223)\end{array}$ & $\begin{array}{c}\text { Chi2 }(1)=4.72 \\
(p=0.0299)\end{array}$ & $\begin{array}{c}0.1698^{* * *} \\
(0.0501) \\
\end{array}$ & $\begin{array}{l}-0.0774^{* * *} \\
(0.0219)\end{array}$ & $\begin{array}{c}\text { Chi2 }(1)=5.60 \\
(p=0.0179)\end{array}$ \\
\hline \multicolumn{7}{|l|}{ Probit models including } \\
\hline (2) Overeducated and undereducated & $\begin{array}{l}0.1632^{* * * *} \\
(0.0496)\end{array}$ & $\begin{array}{c}-0.0408^{* *} \\
(0.0187)\end{array}$ & $\begin{array}{c}\text { Chi2 }(1)=4.75 \\
(p=0.0293)\end{array}$ & $\begin{array}{l}0.1671^{* * * *} \\
(0.0494)\end{array}$ & $\begin{array}{c}-0.0432^{* *} \\
(0.0180)\end{array}$ & $\begin{array}{c}\text { Chi2(1) }=5.75 \\
(p=0.0165)\end{array}$ \\
\hline (3) Working hours & $\begin{array}{l}0.1675^{* * *} \\
(0.0484)\end{array}$ & $\begin{array}{l}-0.0434^{* *} \\
(0.0182)\end{array}$ & $\begin{array}{c}\text { Chi2 }(1)=5.68 \\
(p=0.0172)\end{array}$ & $\begin{array}{l}0.1713^{* * * *} \\
(0.0484)\end{array}$ & $\begin{array}{l}-0.0458^{* * * *} \\
(0.0176)\end{array}$ & $\begin{array}{c}\text { Chi2 }(1)=6.78 \\
(p=0.0092)\end{array}$ \\
\hline (4) Tenure & $\begin{array}{l}0.2211^{* * * *} \\
(0.0607)\end{array}$ & $\begin{array}{l}-0.0782^{* * * *} \\
(0.0247)\end{array}$ & $\begin{array}{l}\text { Chi2 }(1)=9.99 \\
(p=0.0016)\end{array}$ & $\begin{array}{l}0.2244^{* * * *} \\
(0.0609)\end{array}$ & $\begin{array}{c}-0.0804^{* * *} \\
(0.0246)\end{array}$ & $\begin{array}{c}\text { Chi2(1) }=10.7 \\
(p=0.0011)\end{array}$ \\
\hline (5) Tenure and working hours & $\begin{array}{l}0.2250^{* * * *} \\
(0.0594)\end{array}$ & $\begin{array}{l}-0.0806^{* * * *} \\
(0.0241)\end{array}$ & $\begin{array}{l}\text { Chi2 }(1)=11.2 \\
(p=0.0008)\end{array}$ & $\begin{array}{l}0.2285^{* * *} \\
(0.0597)\end{array}$ & $\begin{array}{l}-0.0829^{* * *} \\
(0.0239)\end{array}$ & $\begin{array}{l}\text { Chi2(1) }=11.9 \\
(p=0.0005)\end{array}$ \\
\hline $\begin{array}{l}\text { (6) Tenure, working hours, } \\
\text { overeducated and undereducated }\end{array}$ & $\begin{array}{l}0.2236^{* * *} \\
(0.0595)\end{array}$ & $\begin{array}{l}-0.0798^{* * *} \\
(0.0242) \\
\end{array}$ & $\begin{array}{l}\text { Chi2(1) }=10.9 \\
(p=0.0010)\end{array}$ & $\begin{array}{l}0.2273^{* * *} \\
(0.0598)\end{array}$ & $\begin{array}{c}-0.0822^{* * * *} \\
(0.0240) \\
\end{array}$ & $\begin{array}{c}\text { Chi2(1) }=11.7 \\
(p=0.0006)\end{array}$ \\
\hline \multicolumn{7}{|l|}{ Probit models excluding } \\
\hline (7) Occupation dummies & $\begin{array}{l}0.1586^{* * *} \\
(0.0539)\end{array}$ & $\begin{array}{l}-0.0378^{*} \\
(0.0219)\end{array}$ & $\begin{array}{l}\text { Chi2 }(1)=2.98 \\
(p=0.0844)\end{array}$ & $\begin{array}{l}0.1629^{* * *} \\
(0.0534)\end{array}$ & $\begin{array}{l}-0.0403^{*} \\
(0.0209)\end{array}$ & $\begin{array}{c}\text { Chi2(1) }=3.69 \\
(p=0.0546)\end{array}$ \\
\hline (8) Industry dummies & $\begin{array}{l}0.1585^{* * *} \\
(0.0505)\end{array}$ & $\begin{array}{l}-0.0384^{* *} \\
(0.0190)\end{array}$ & $\begin{array}{l}\text { Chi2 }(1)=4.09 \\
(p=0.0430)\end{array}$ & $\begin{array}{l}0.1626^{* * *} \\
(0.0503)\end{array}$ & $\begin{array}{l}-0.0408^{* *} \\
(0.0182)\end{array}$ & $\begin{array}{l}\text { Chi2(1) }=5.05 \\
(p=0.0246)\end{array}$ \\
\hline (9) Firm size dummies & $\begin{array}{l}0.1628^{* * *} \\
(0.0513)\end{array}$ & $\begin{array}{l}-0.0409^{* *} \\
(0.0196)\end{array}$ & $\begin{array}{l}\text { Chi2 }(1)=4.34 \\
(p=0.0372)\end{array}$ & $\begin{array}{l}0.1667^{* * *} \\
(0.0513)\end{array}$ & $\begin{array}{l}-0.0429^{* *} \\
(0.0191)\end{array}$ & $\begin{array}{l}\text { Chi2(1) }=5.03 \\
(p=0.0249)\end{array}$ \\
\hline (10) Country dummies & $\begin{array}{l}0.2134^{* * *} \\
(0.0508)\end{array}$ & $\begin{array}{l}-0.0700^{* * * *} \\
(0.0191)\end{array}$ & $\begin{array}{l}\text { Chi2(1) }=13.4 \\
(p=0.0002)\end{array}$ & $\begin{array}{l}0.2122^{* * * *} \\
(0.0491)\end{array}$ & $\begin{array}{c}-0.0698^{* * * *} \\
(0.0188)\end{array}$ & $\begin{array}{c}\text { Chi2(1) }=13.7 \\
(p=0.0002)\end{array}$ \\
\hline $\begin{array}{l}\text { (11) Occupation, industry and } \\
\text { firm size dummies }\end{array}$ & $\begin{array}{l}0.1567^{* * *} \\
(0.0550)\end{array}$ & $\begin{array}{l}-0.0369^{*} \\
(0.0219)\end{array}$ & $\begin{array}{l}\text { Chi2 }(1)=2.84 \\
(p=0.0918)\end{array}$ & $\begin{array}{l}0.1613^{* * *} \\
(0.0547)\end{array}$ & $\begin{array}{l}-0.0394^{*} \\
(0.0209)\end{array}$ & $\begin{array}{l}\text { Chi2(1) }=3.53 \\
(p=0.0603)\end{array}$ \\
\hline $\begin{array}{l}\text { (12) Occupation, industry, firm size } \\
\text { and country dummies }\end{array}$ & $\begin{array}{l}0.2209^{* * * *} \\
(0.0609)\end{array}$ & $\begin{array}{l}-0.0746^{* * * *} \\
(0.0261)\end{array}$ & $\begin{array}{l}\text { Chi2(1) }=8.15 \\
(p=0.0043)\end{array}$ & $\begin{array}{l}0.2214^{* * *} \\
(0.0584)\end{array}$ & $\begin{array}{l}-0.0743^{* * * *} \\
(0.0252)\end{array}$ & $\begin{array}{c}\text { Chi2(1) }=8.69 \\
(p=0.0032)\end{array}$ \\
\hline
\end{tabular}

The informal learning dependant variable is standardised. All above estimations are based on the same sample of 25,633 observations. Estimations with 1 instrument use the standardised unemployment rate and estimations with 3 instruments add the interactions of the standardised unemployment rate with 2 of the 3 dummies of EPL for permanent employment. All regressions include the same control variables as reported in Table 3, with the only exception mentioned for each robustness check. The outcome model remains the same as reported in Table 3. Standard errors clustered at country level are shown in parenthesis. ${ }^{*} p<0.10,{ }^{* *} p<0.05,{ }^{* * *} p<0.01$. 
Table A4. Wooldridge's IV robust estimations of informal learning intensity

\begin{tabular}{|c|c|c|}
\hline & $\begin{array}{c}\text { (1) } \\
\text { Robust IV } \\
\text { (1 instrument) }\end{array}$ & $\begin{array}{c}\text { (2) } \\
\text { Robust IV } \\
\text { (3 instruments) }\end{array}$ \\
\hline \multicolumn{3}{|l|}{ Informal Learning Equation } \\
\hline Temporary contract & $\begin{array}{l}0.6334^{* * *} \\
(0.1089)\end{array}$ & $\begin{array}{c}0.6513^{* * *} \\
(0.1155)\end{array}$ \\
\hline Age & $\begin{array}{l}-0.0108^{* *} \\
(0.0046)\end{array}$ & $\begin{array}{l}-0.0108^{* *} \\
(0.0046)\end{array}$ \\
\hline Age $^{2}$ & $\begin{array}{l}-0.0000 \\
(0.0001)\end{array}$ & $\begin{array}{l}-0.0000 \\
(0.0001)\end{array}$ \\
\hline Years of education & $\begin{array}{l}0.0174^{* * *} \\
(0.0038)\end{array}$ & $\begin{array}{l}0.0174^{* * *} \\
(0.0039)\end{array}$ \\
\hline Overeducated & $\begin{array}{l}-0.1136^{* * *} \\
(0.0163)\end{array}$ & $\begin{array}{l}-0.1139^{* * *} \\
(0.0165)\end{array}$ \\
\hline Undereducated & $\begin{array}{l}0.1551^{* * *} \\
(0.0266)\end{array}$ & $\begin{array}{l}0.1552^{* * *} \\
(0.0266)\end{array}$ \\
\hline Working hours & $\begin{array}{l}0.0071^{* * *} \\
(0.0012)\end{array}$ & $\begin{array}{l}0.0071^{* * *} \\
(0.0012)\end{array}$ \\
\hline Tenure & $\begin{array}{c}0.0005 \\
(0.0015)\end{array}$ & $\begin{array}{c}0.0006 \\
(0.0016)\end{array}$ \\
\hline Elaborate learning & $\begin{array}{l}0.2041^{* * *} \\
(0.0145)\end{array}$ & $\begin{array}{l}0.2041^{* * *} \\
(0.0145)\end{array}$ \\
\hline _cons & $\begin{array}{c}-0.6280^{* * *} \\
(0.1496)\end{array}$ & $\begin{array}{c}-0.6440^{* * *} \\
(0.1562)\end{array}$ \\
\hline Occupation dummies & yes & yes \\
\hline Industry \& firm size dummies & yes & yes \\
\hline Country dummies & yes & yes \\
\hline $\begin{array}{l}\text { Temporary Contract Equation } \\
\text { Unemployment }\end{array}$ & $\begin{array}{c}A M E \\
0.0140^{* *} \\
(0.0059)\end{array}$ & $\begin{array}{c}A M E \\
0.0219^{* * *} \\
(0.0044)\end{array}$ \\
\hline Unemployment * EPL moderate & & $\begin{array}{c}-0.0119^{* * * *} \\
(0.0045)\end{array}$ \\
\hline Unemployment * EPL low & & $\begin{array}{c}-0.0523^{* * *} \\
(0.0098)\end{array}$ \\
\hline$N$ & 25,366 & 25,366 \\
\hline$R^{2}$ & 0.1479 & 0.1461 \\
\hline
\end{tabular}

The standardised unemployment rate is used as instrument in column (1), and column (2) adds as instruments the interactions of the standardised unemployment rate with 2 of the 3 dummies of EPL for permanent employment. AME correspond to Average Marginal Effects. Standard errors clustered at country level are shown in parenthesis. ${ }^{*} p<0.10,{ }^{* *} p<0.05,{ }^{* * *} p<0.01$. 